\title{
ACCELERATED SOLVENT EXTRACTION - MORE EFFICIENT EXTRACTION OF POPS AND PAHS FROM REAL CONTAMINATED PLANT AND SOIL SAMPLES
}

Andreas Hubert, Klaus-Dieter Wenzel', Werner Engelwald ${ }^{1}$ and Gerrit Schüürmann

UFZ Centre for Environmental Research, Department of Chemical

Ecotoxicology, Permoserstr. 15, D-04318 Leipzig, Germany

'University of Leipzig, Faculty for Chemistry and Mineralogy, Institute for Analytical Chemistry, Linnéstrasse 3, D-04103 Leipzig, Germany

\section{TABLE OF CONTENTS}

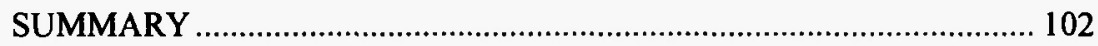

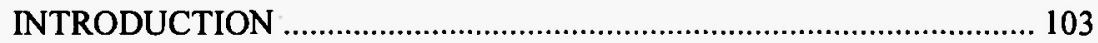

1.EXTRACTION TECHNIQUES IN ENVIRONMENTAL ANALYSIS 104

1.1 Requirements on modern procedures ............................................. 104

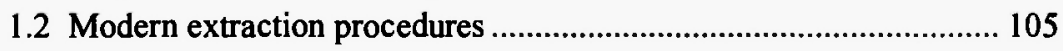

1.3 Design and function of the ASE 200 extraction unit ...................... 107

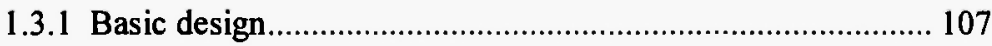

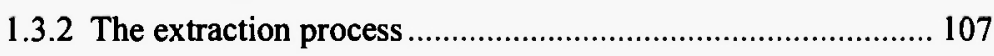

1.3.3 Selection of the solvent ...................................................... 113

2. DEVELOPMENT OF A WORK STRATEGY ……........................... 116

2.1 Extraction problems from different environmental compartments ... 116

2.2 Aims of methodological improvements........................................ 117

2.3 Working hypothesis and the resulting work programme …............. 117

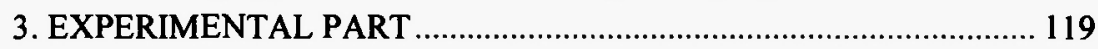

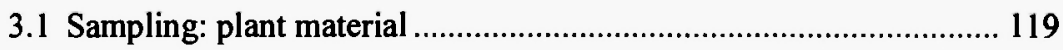

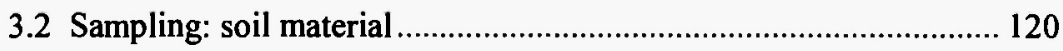

Corresponding address: Klaus-Dieter Wenzel, UFZ Centre for Environmental Research, Department of Chemical Ecotoxicology, Permoserstr. 15, D-04318 Leipzig, Germany. E-mail:kw@uoe.ufz.de 


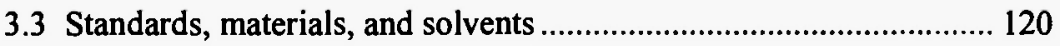

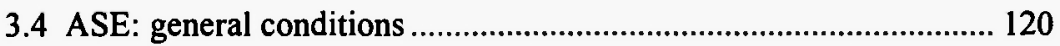

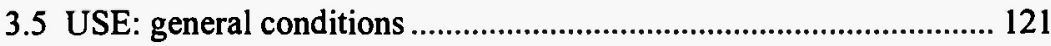

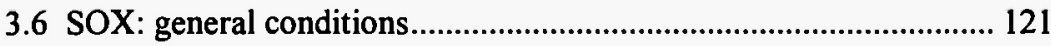

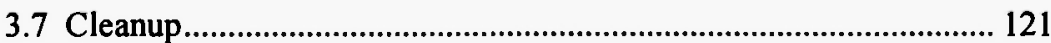

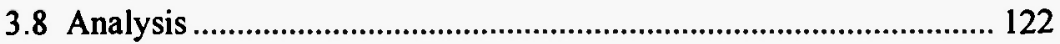

4. OPTIMIZED EXTRACTION OF PLANT SAMPLES .......................... 122

4.1 ASE in environmental analysis ................................................... 122

4.2 Application notes for soils - starting-point of initial tests............... 122

4.3 Influence on the extraction efficiency ......................................... 124

4.3.1 Influence of extraction pressure ............................................ 124

4.3.2 Influence of solvent ................................................................ 124

4.3.3 Influence of extraction temperature ......................................... 124

4.4 Comparison between ASE and USE using real plant samples ........ 127

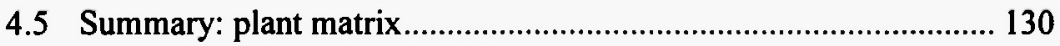

5. OPTIMIZED EXTRACTION OF SOIL SAMPLES ………................... 131

5.1 Goal of the investigations ............................................................ 131

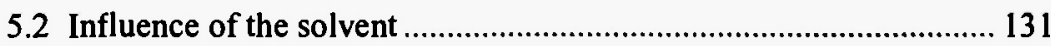

5.3 Comparison between ASE and SOX using real soil samples .......... 132

5.4 Influence of extraction temperature................................................. 132

5.5 Dependence of the RSD on the extraction temperature................... 139

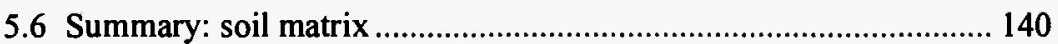

6. REASONS FOR THE MAXIMUM EXTRACTION EFFICIENCY ..... 141

7. CONCLUSIONS AND FUTURE OUTLOOK …................................... 141

\section{SUMMARY}

Accelerated solvent extraction (ASE) is extraordinarily effective once the operating variables solvent, temperature and pressure have been optimized. The extraction temperatures of 40 and $120^{\circ} \mathrm{C}$ for plant samples and 80 and $140{ }^{\circ} \mathrm{C}$ for soil samples represent key temperatures for the extraction of persistent organic pollutants (POPs) and polycyclic aromatic hydrocarbons (PAHs) from real contaminated sample material. At these temperatures the highest extraction efficiency is reached. The efficiency increases with the complexity of matrix and the degree of multiple contamination of the sample. ASE provides a better extraction quality often with higher analysis findings for organochlorines $(\mathrm{HCH}$ isomers, $p, p-\mathrm{DDT}$ and its degradation products 
$p, p^{\prime}$-DDE and $p, p^{\prime}$-DDD, chlorobenzenes, polychlorinated biphenyls) and PAHs, exceeding conventional techniques such as ultrasonic extraction and Soxhlet extraction up to 1-2 orders of magnitude.

\section{INTRODUCTION}

In contrast to certified and spiked material, it is impossible to say whether only $1 \%, 10 \%$ or even $100 \%$ of a substance of interest has been extracted from real contaminated environmental samples. The more realistic the detected pollutant concentration accumulated in the sample matrix, the better ecotoxicological assessments (assessments of exposure and distribution in environmental compartments, causal links between the dose and effect of pollutants) can be carried out $/ 1 /$.

The accuracy of ecotoxicological parameters therefore directly depends on the quality of basic analytical procedures such as extraction, cleanup and measurement. These procedures need to be continuously modified as the state of the art and the equipment used improve. The aim of ecotoxicological analysis is to attain maximum extraction efficiency for the substance of interest in any environmental matrix. This entails constantly enhancing cleanup techniques to obtain clean chromatograms and hence unambiguous identification and quantification. These objectives necessitate using trace analysis techniques of the highest selectivity and sensitivity; GC/MS methods are especially suitable when ${ }^{13} \mathrm{C}$-marked or deuterated reference substances are used for matrix-specific pollutant measurements. The quality of the techniques and analysis used should therefore be at a similarly high level, irrespective of whether a simple matrix such as adsorber resins employed for the adsorption of organic pollutants in air analysis (e.g. XAD) or complicated soil and plant matrices with numerous possible interfering components are used. Another goal is to simplify the previous techniques used. Aspects here include shortening extraction times, reducing the amounts of solvents used, automating procedures, ensuring good reproducibility, matrix-specific optimization, and simple handling. Therefore the ultimate aim is to perform highly efficient extraction and cleanup in as few working steps as possible. The first step in the qualitative and quantitative analysis of plant and soil components is extraction, i.e. separating the substances to be analysed from the cell or soil matrix. When trying to improve analysis methods, of all the extraction techniques currently available Accelerated Solvent Extraction 
(ASE) appeared to be best suited for increasing extraction efficiency owing to the large variability in temperature and pressure, which can be used, as well as the fact that individual extractants (and mixtures thereof) with very different polarity can be employed. We describe below a way of optimizing ASE, which has been used internationally for years, and compare it with conventional extraction techniques such as ultrasonic extraction and Soxhlet extraction (SOX) for the extraction of POPs (persistent organic pollutants) and PAHs (polycyclic aromatic hydrocarbons) from plant compartments and soils. The extraction method was optimized using real sample material from natural systems with a view to practical ecotoxicological usage.

\section{EXTRACTION TECHNIQUES IN ENVIRONMENTAL ANALYSIS}

\subsection{Requirements on modern procedures}

The following properties are expected of modern techniques for the extraction of POPs from environmental samples $/ 2 /$ :

- Fast extraction (no longer than 10-30 minutes in total)

- Low solvent consumption (no more than $12-30 \mathrm{~mL}$ for a sample weighing about $10 \mathrm{~g}$ )

- The ability to fractionate the samples

- Automatic extraction

- Large variability in the extraction variables temperature, pressure and solvents

- Maximum extraction efficiency in the matrix-specific optimization of the procedure

Special attention should be paid to these aspects when choosing a suitable extraction technique. For selecting and carrying out a suitable extraction procedure in the analysis lab, other factors to be considered include the scientific objectives, whether routine or basic research is involved, and also financial considerations. 


\subsection{Modern extraction procedures}

In many environmental research laboratories, the majority of labour and time is taken up by sample preparation. Previously manual, lengthy and solvent-intensive liquid extraction techniques were used to separate the analytes from the matrix and to enrich them. They included conventional liquid methods such as SOX taking $2-48 \mathrm{~h}$ and consuming $50-500 \mathrm{~mL}$ of solvent per sample $/ 2 /$. The reason for the long extraction times and the high solvent requirement is the poor penetration of the sample material by the solvent. This results in matrix-analyte-interactions being inadequately influenced.

Only in recent years have new extraction techniques been developed which reduce extraction times and solvent consumption, and which can also be automated. They include automated Soxhlet extraction (Soxtec), microwave extraction (MWE), ultrasonic extraction (USE) and supercritical fluid extraction (SFE). All these extraction techniques are optimized to the respective matrix and are good alternatives to SOX. Nevertheless, these techniques differ in terms of solvent consumption, extraction times and the degree of automation.

Although Soxtec extraction time is shorter $/ 2,3 /$, it still takes a few hours (1-24 h with a solvent consumption of $50-100 \mathrm{~mL}$ ). The extraction of soil samples is generally carried out using toluene $14,5 /$. This is an optimized method whose application is precisely laid down by international regulations. MWE is a new technique which reduces extraction times down to around 10 $\min / 6-8 /$. However, it has the disadvantages that the extracts take a long time to cool down (the extraction vessels are made of Teflon, which is known for its poor heat conductivity) and that the extract needs to be separated from the residue by filtration. Furthermore, the choice of solvent is limited as it must contain components which are excited by microwaves. For example, pure hydrocarbons such as $n$-hexane, which is frequently used for the extraction of semivolatile organic compounds, are unsuitable.

The commonly used procedure of USE represents a significant improvement over SOX concerning the time and solvent consumption required (10-60 min with solvent consumption of $150-300 \mathrm{~mL}$ )/9-13/. This method is up to now presently or preferred for the extraction of semivolatile anthropogenic organics from plant material.

In recent years, particular attention has been paid to SFE, since it enables selective extraction with liquefied $\mathrm{CO}_{2}$ by setting suitable extraction 
conditions, the parameters such as temperature and pressure being variable /14-18/. The disadvantage is the small polarity of the extraction agent, which can only be increased to a limited extent by adding polar methanol (up to $10 \%)$ as a modifier. Lower recovery rates are especially striking in the plant matrix. Polar matrix components can act as polar modifiers. This can lead to a poorer reproducibility. This matrix dependency impedes method development and prevents the routine use of SFE. A further topic may be a blockage of the restrictor when the $\mathrm{CO}_{2}$ expands.

One of the latest extraction methods is pressurized liquid extraction (PLE). One type of PLE is ASE (a trademark of Dionex), which has been used internationally for about five years $/ 2,19-25 /$. It has been certified by the US Environmental Protection Agency (EPA), e.g. in Method 3545 from soils, which includes PCBs, PAHs, organochlorines and organophosphorous pesticides $125,26 /$. In addition to improved automation, it enables much shorter extraction times and consumes smaller quantities of solvent. Extractions can be carried out within a range from room temperature (very mild conditions) up to $200^{\circ} \mathrm{C}$, and at pressures of 3-200 atm (0.3-20 MPa), in order to keep the solvent in a liquid state during the extraction process. The advantage over some of the techniques used previously is that the pressure, temperature and polarity of the solvent (individually or mixed) can be chosen from a large range depending on the respective matrix and substance palette. Like SFE, ASE requires less solvent than conventional techniques such as USE. Extraction can take place sequentially, and automation enables individual sources of error to be largely ruled out. This helps reduce solvent costs, improves analytical recovery, and also shortens extraction and processing times (since smaller amounts of solvent are vaporized).

However, experiments conducted by some groups comparing the results of ASE with accepted techniques specified in standardized methods (SOX) merely indicated that the extraction efficiency was similar $/ 4 /$.

Investigations into ASE have previously only focused on applications for the soil matrix $/ 4,21,27-29 /$, sludge $/ 4,27 /$, sediments $/ 5,9,29 /$, fly ash $/ 29 /$ and road dust $/ 29 /$. Systematic studies into the extraction of pollutants from the plant or soil matrix are hitherto unknown. 


\subsection{Design and function of the ASE 200 extraction unit}

\subsubsection{Basic design}

Figure 1 shows the basic design of the extraction unit. The sample is contained in a stainless steel extraction cell which during extraction is placed inside the oven. The vials have metals frits and high-pressure gaskets at both ends. The vials are closed by simply tightening the frits by hand; no tools are required. The cell is positioned vertically in the oven, and the solvent is then inserted from above. The ASE extractor features a pump to feed the solvent and which adjusts the extraction pressure (Figure 2). Valves are located between the pump and the extraction cell; the pump valve enables the cell to be filled with the extractant while the purge valve is used to purge the pipes and the cell with an inert gas. In order to perform static extractions, another valve is located in the pipe between the extraction cell and the sample collecting vessel (the static valve). Extraction is carried out by placing solid sample material in the extraction cell. Liquid samples can only be extracted by using carrier materials such as sea sand; direct extraction of liquids is not possible. The extraction cell volumes have an optional size of $1,5,11,22$ and $33 \mathrm{ml}$, while the new ASE 300 (first produced in 2000) has a cell volume of up to $100 \mathrm{ml}$.

\subsubsection{The extraction process}

The sample material is weighed and placed inside the extraction cell. Any dead volume is filled up with sea sand, hydromatrix to adsorb water or Florisil $^{\otimes}$ as a kind of precleanup. The cell is screwed tight manually and placed into the sample carousel.

Step 1: Loading the cell

After the extraction method has been selected via the control panel on the unit or with the PC software AutoASE (Dionex) and started, the extraction cell and the sample collecting vessel are automatically moved to the programmed position. A needle mechanism pierces the membrane of the sample collecting vessel, and the cell is automatically transported into the oven. The cell is sealed by the application of pressure (Figure 3 ).

Step 2: Filling the cell

The pump begins to pump the solvent into the cell. After the cell has been completely filled up and about $1 \mathrm{~mL}$ of solvent has overflowed into the 


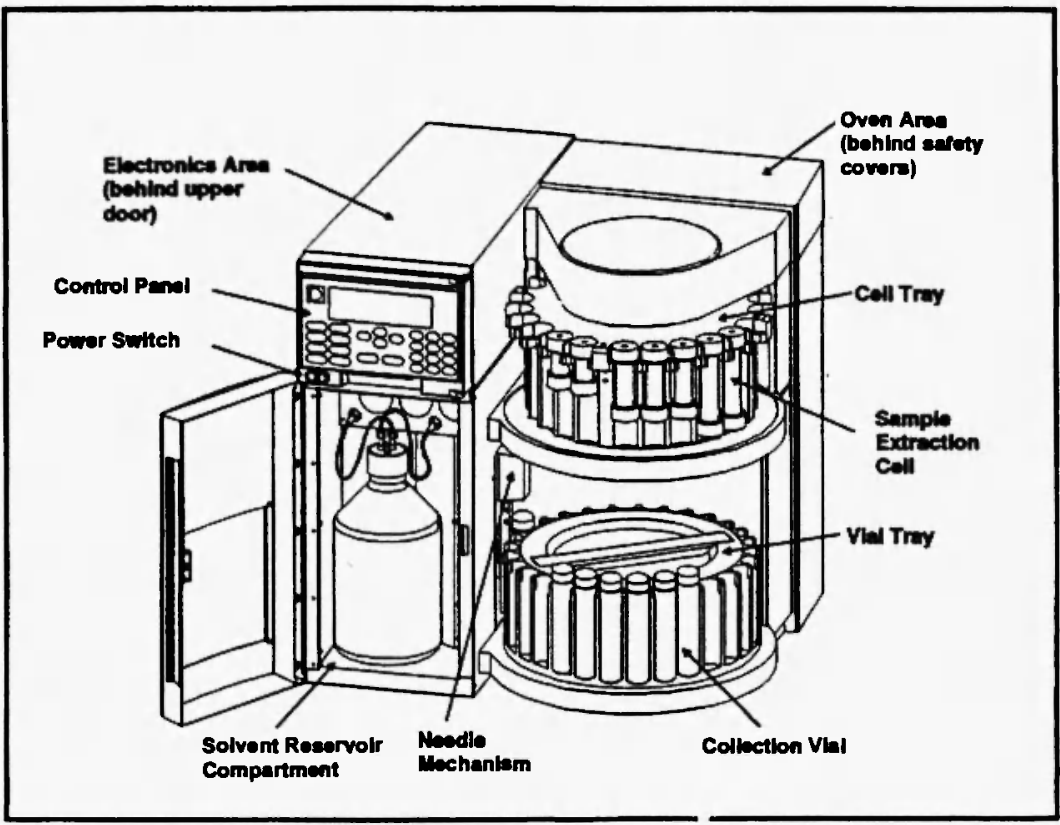

Fig. 1: Basic Design of the Extraction Unit ASE 200

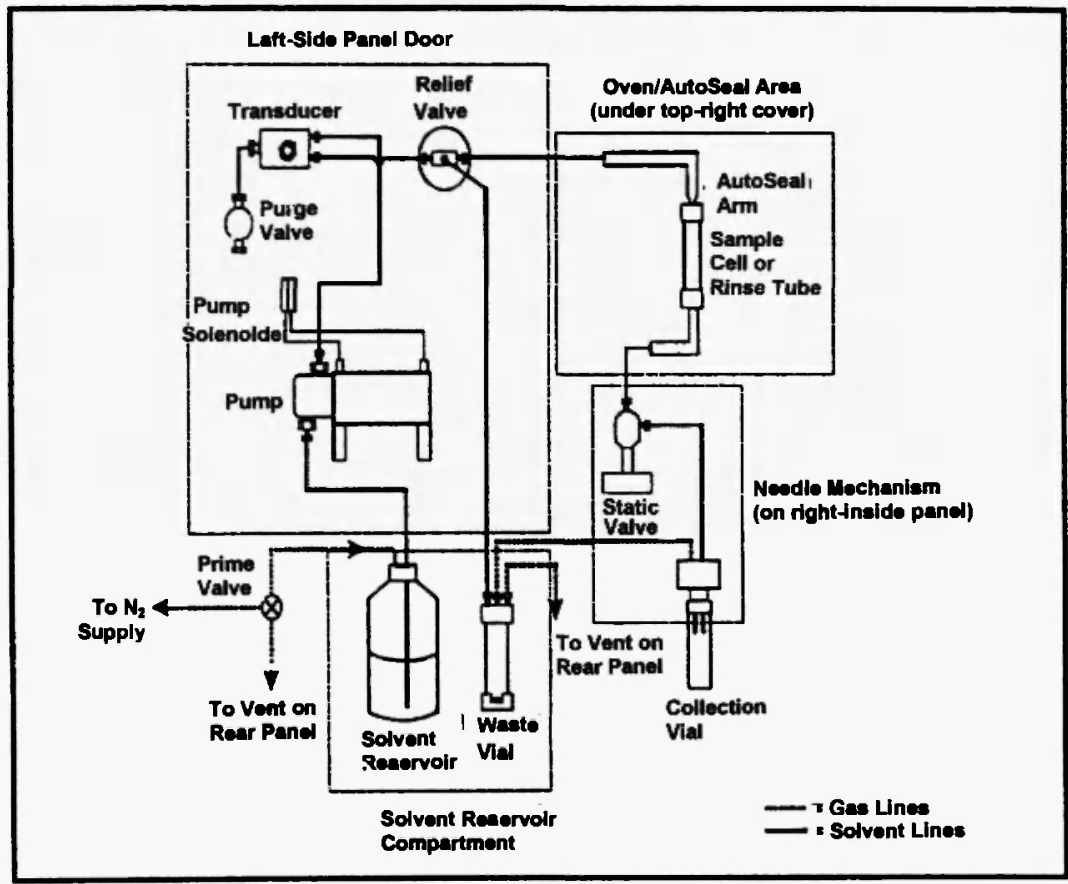

Fig. 2: Schematic Description of an ASE Unit 


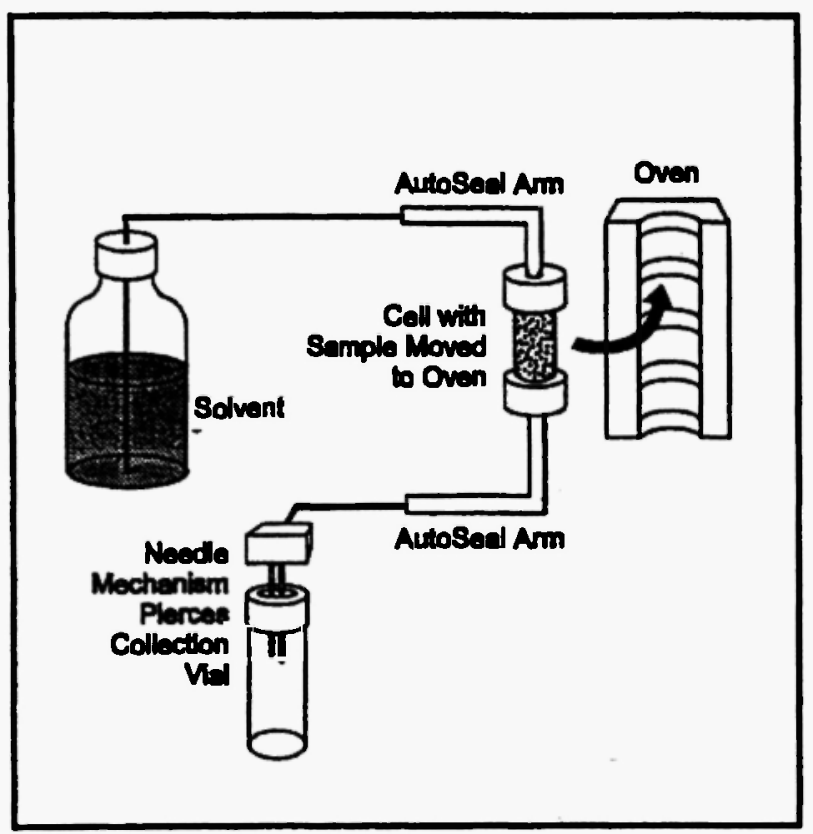

Fig. 3: Extraction Process: Loading the Cell

sample collecting vessel, the static valve is closed and the solvent stops flowing (Figure 4).

Step 3 and 4: Heating and static

The cell is heated up to the temperature entered, remaining in thermal equilibrium (preheat time up to $8 \mathrm{~min}$ ). Once the temperature set has been reached, the static cycle begins. The static cycle is usually performed 3 times for most extractions. The length of each cycle varies depending on the sample material to be studied, but is generally around $10 \mathrm{~min}$. During static extraction, the pressure rises in the cell. As soon as the desired pressure has been reached (about $1500 \mathrm{psi}$ ), the static valve opens at periodic intervals to regulate the extraction pressure adjusted in the cell (Figure 5 ).

\section{Step 5: Flushing}

After the first static cycle is complete, the static valve opens, the extract flows into the sample collecting vessel and fresh solvent is pumped into the extraction cell (50-100\% of the cell volume). Then the other static cycles take place (Figure 6). 


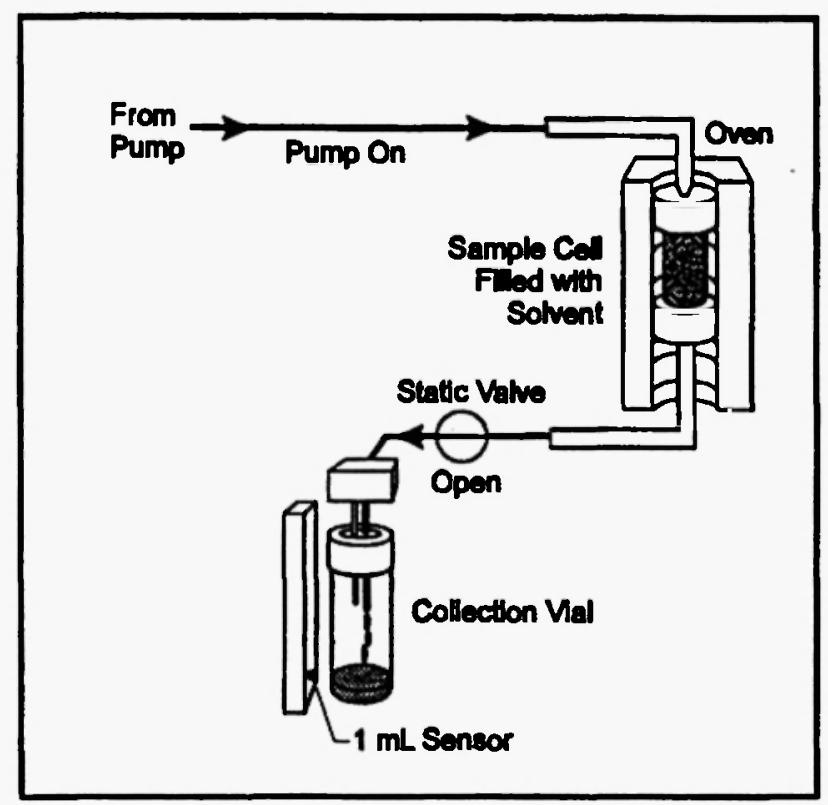

Fig. 4: Extraction Process: Filling the Cell

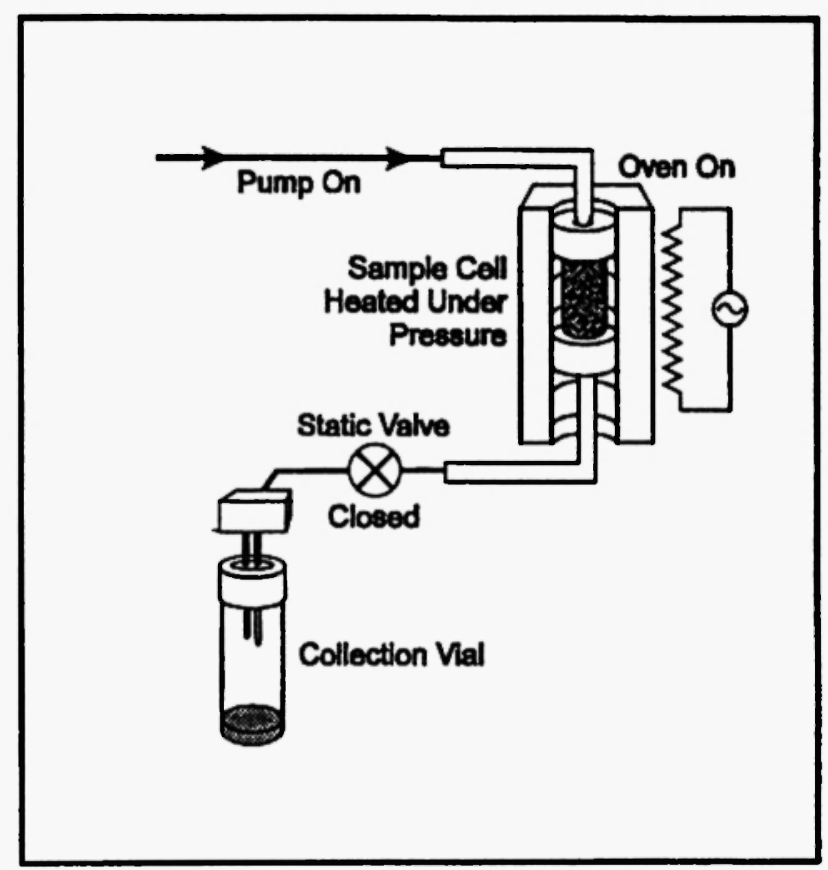

Fig. 5: Extraction Process: Heating and Static 


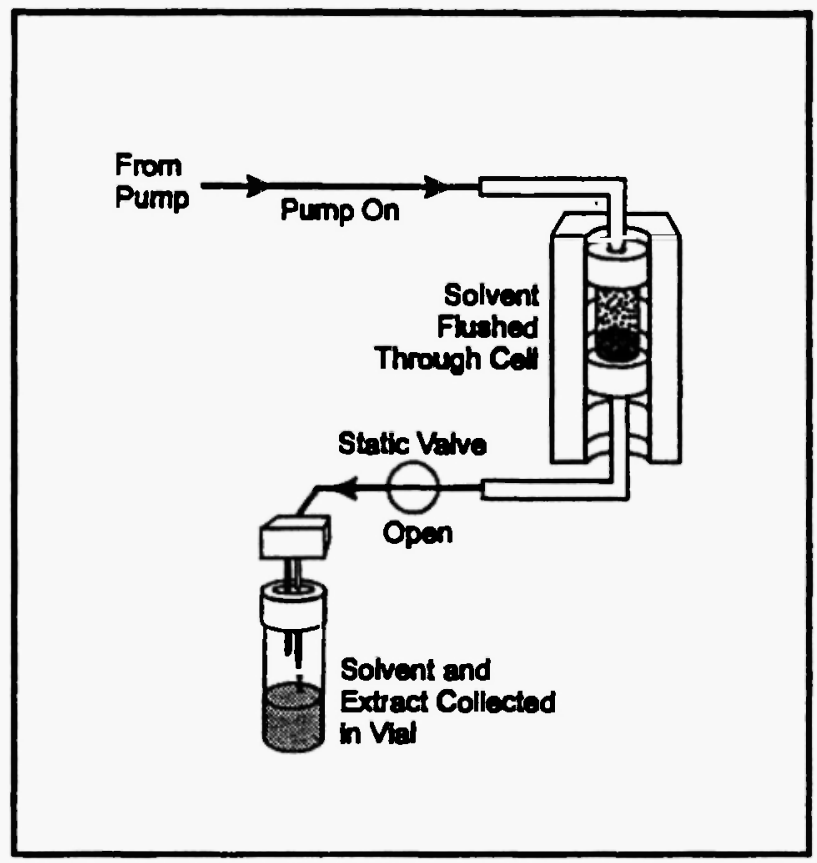

Fig. 6: Extraction Process: Flushing

\section{Step 6: Purging}

When the extraction is over, the remaining solvent is purged out of the cell by means of nitrogen. The sample collecting vessel now contains all the solvent along with the analytes extracted from the sample (Figure 7).

Step 7: End relief

The cell still remains in the oven until the extraction pressure has been completely relieved (Figure 8 ).

Step 8: Unloading the cell

The pressure is bled out of the system, the cell is transported from the oven back to the sample carousel, the needle mechanism is removed from the sample collecting vessel, and the carousel lines up the next sample. The ASE 200 stops when all the samples (up to 24) have been extracted (Figure 9). 


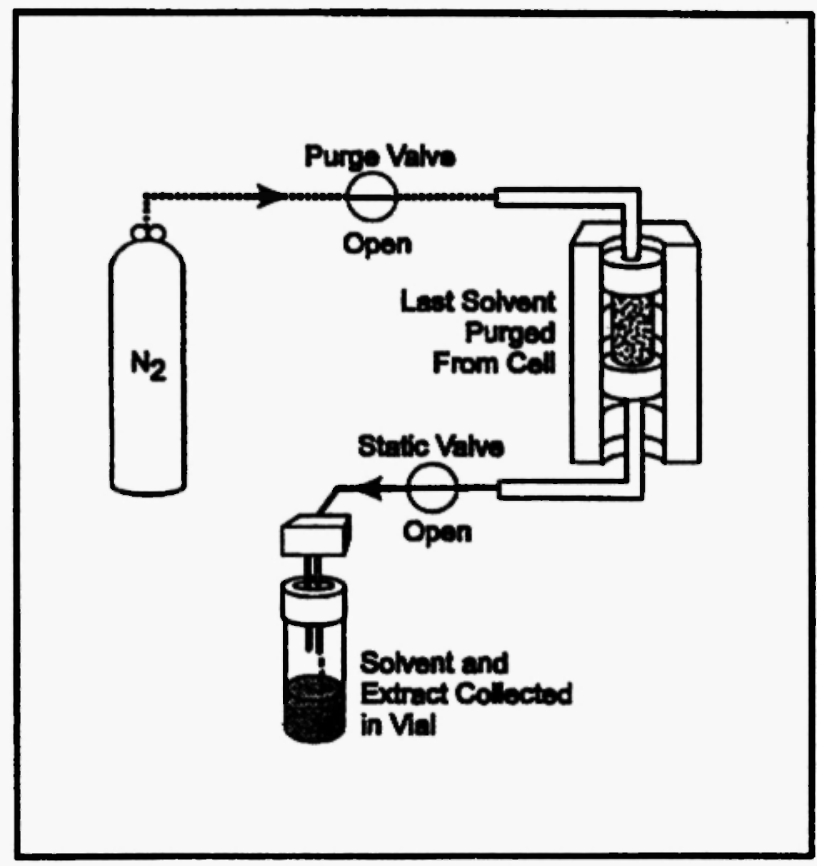

Fig. 7: Extraction Process: Purging

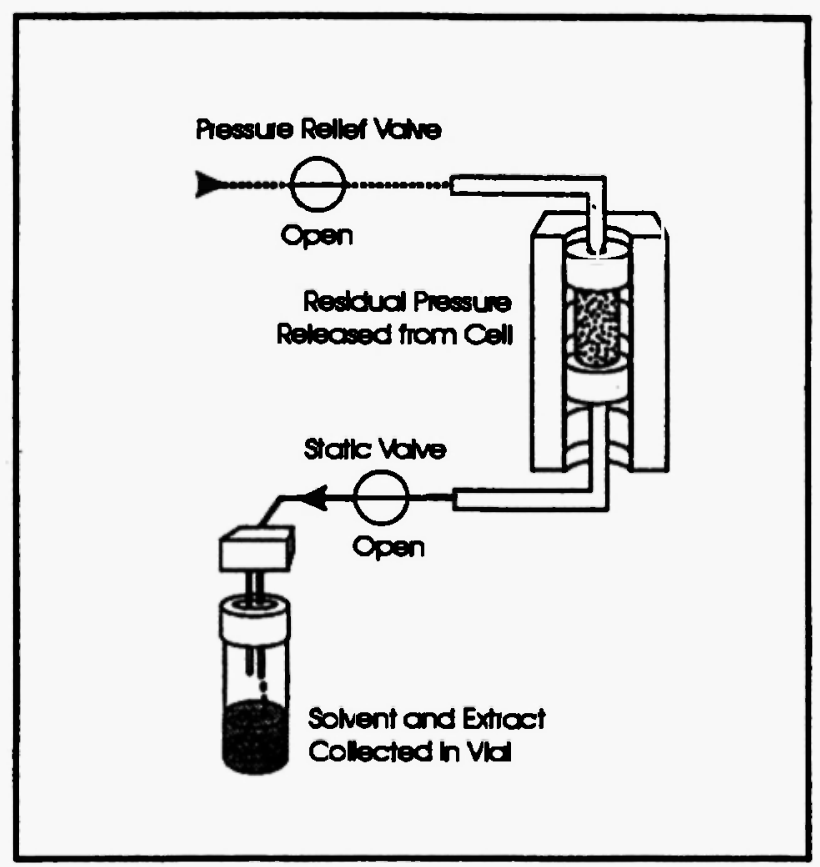

Fig. 8: Extraction Process: End Relief 


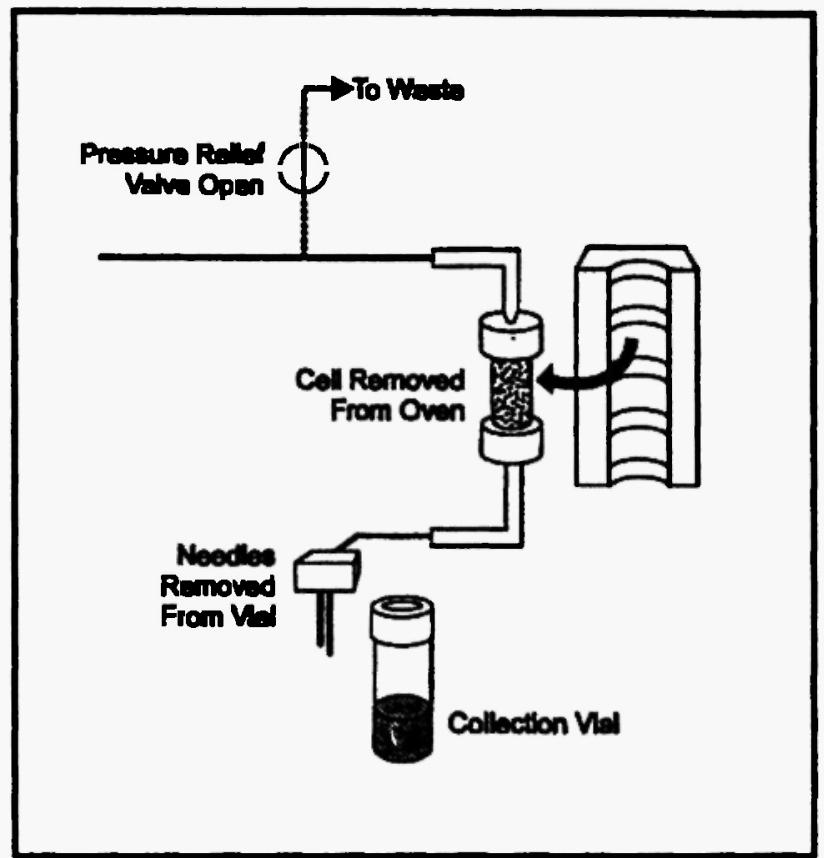

Fig. 9: Extraction Process: Unloading the Cell

\subsubsection{Selection of the solvent}

Apart from a few exceptions, the most different solvents can be used for ASE. Organic and aqueous solvents are suitable, as well as acids and bases. No solvent may be used with an autoignition point of 40 to $200{ }^{\circ} \mathrm{C}$ (e.g. carbon disulfide, diethylether, 1,4-dioxane).

When selecting a suitable extractant, eluotropic series are helpful as they can be used to estimate the polarity of these solvents (Table 1). By selecting suitable solvents between the values of $0=n$-hexane and $>1=$ water, almost the entire range of polarity can be covered, enabling the best solvents to be chosen for the pollutants concerned. The physico-chemical properties such as boiling point, thermal stability, density (important parameters for a good penetration in the sample matrix) and human-toxicological effects (e.g. carcinogenic effect of benzene) of the solvents must be considered. For the extraction of lipophilic analytes the solvents n-hexane, toluene, dichloromethane and mixtures of these solvents are particularly suitable. Table 2 shows all the solvents used and the extraction parameters for the extraction tests carried out. 
Table 1

Eluotropic Row (According to Trappe) for Selection of the Solvents

\begin{tabular}{|c|c|c|c|}
\hline solvent & polarity & solvent & polarity \\
\hline n-hexane & 0.00 & 2-butanone & 0.51 \\
\hline isooctane & 0.01 & acetone & 0.56 \\
\hline petroleum ether & 0.01 & dioxane & 0.56 \\
\hline n-decane & 0.04 & ethyl acetate & 0.58 \\
\hline cyclohexane & 0.04 & methyl acetate & 0.60 \\
\hline cyclopentane & 0.05 & pentanol & 0.61 \\
\hline 1-pentene & 0.08 & dimethyl sulfoxide & 0.62 \\
\hline carbon disulfide & 0.15 & diethylamine & 0.63 \\
\hline 4-chloromethane & 0.18 & nitromethane & 0.64 \\
\hline xylene & 0.26 & acetonitrile & 0.65 \\
\hline isopropyl ether & 0.28 & pyridine & 0.71 \\
\hline toluene & 0.29 & butylcellosolve & 0.74 \\
\hline chlorobenzene & 0.30 & iso- + n-propanol & 0.82 \\
\hline benzene & 0.32 & ethanol & 0.88 \\
\hline diethyl ether & 0.38 & methanol & 0.95 \\
\hline chloroform & 0.40 & ethylene glycol & 1.11 \\
\hline $\begin{array}{l}\text { methylene } \\
\text { chloride }\end{array}$ & 0.42 & acetic acid & large \\
\hline methylpentanone & 0.43 & water & larger \\
\hline tetrahydrofuran & 0.45 & salt and buffers & very large \\
\hline
\end{tabular}




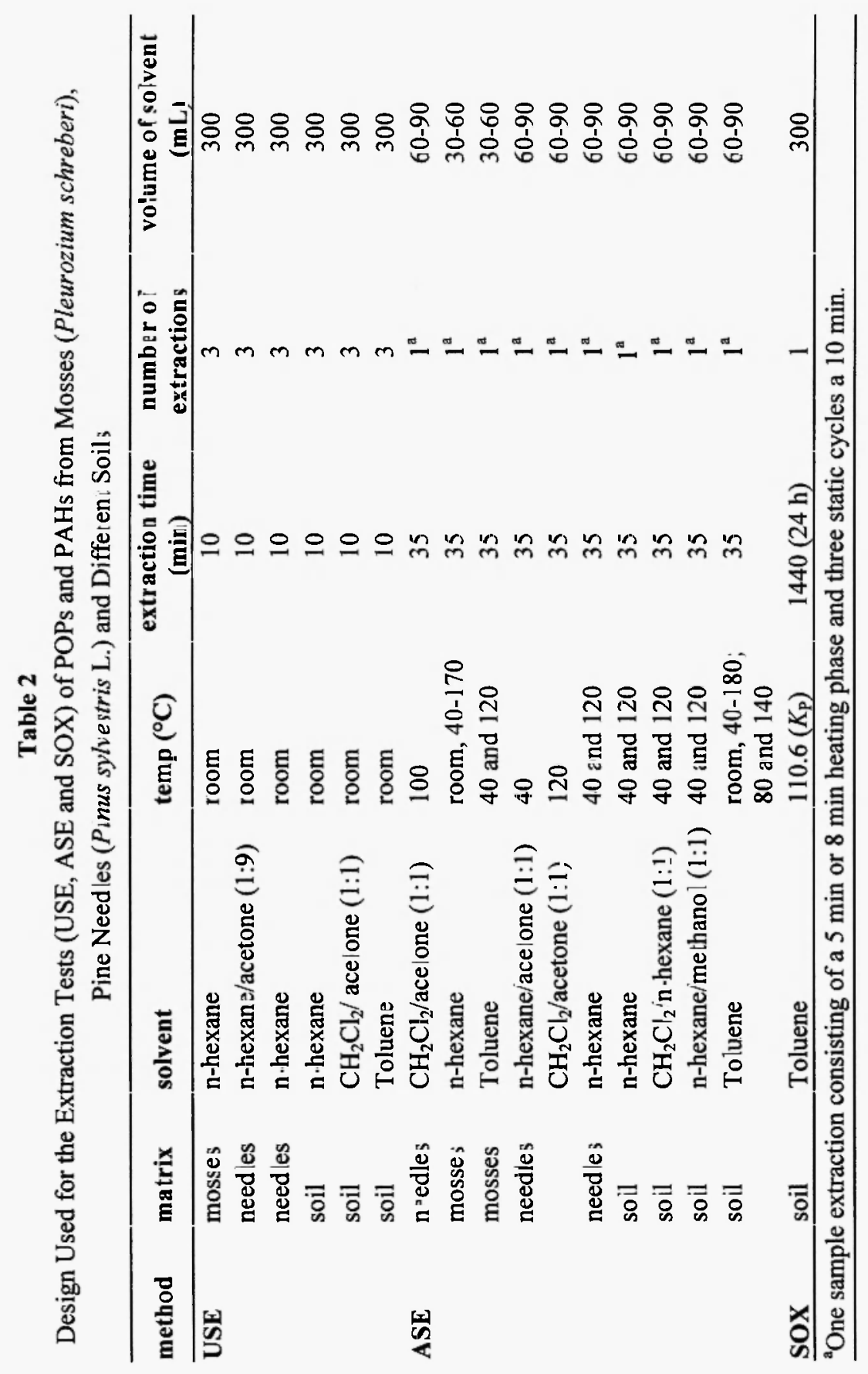




\section{DEVELOPMENT OF A WORK STRATEGY}

\subsection{Extraction problems from different environmental compartments}

Initial investigations were made into aspects of exposure and bioavailability for POPs and PAHs in pine needles acting as regional and global bioindication systems $/ 30-32 /$. The complicated needle matrix contains high fractions of lipid-rich structures. Differences among the same and different plant species $/ 33$ / depend on location, and the effect of numerous other factors of influence all place high demands on extraction, cleanup and analysis /34-36/. The plant matrix usually proved much harder to handle than the soil matrix we later included in our investigations $/ 37 /$. Nevertheless, during the large number of extractions performed, one striking observation was the unexpected and inexplicably low extraction efficiency of samples from certain locations accompanied by unusual interference in the GC-MS chromatograms. Extraction was performed using the USE, which had also been chosen by other leading groups of scientists $/ 12,13 /$ working in the same field. Analytical interference was also especially encountered in plants a few years old owing to multiple exposure to impurities depending on their location. As a result, higher concentrations of other pollutants occurring alongside the substances being investigated in the matrix can act as considerable interference factors during sample analysis.

It was known that the ASE of POPs and PAHs from certified and spiked soils, sediments and plant material, including precision and systematic deviation, results in recovery data comparable with those from other common extraction methods $/ 4,38 /$.

However, these actual conditions did not match the fundamental ecotoxicological requirements for analytical method development, which fulfills the following criteria:

- low, medium and high contamination (referring to the total multiple contamination, not just contamination with the substances to be identified);

- simple, medium and complicated matrices (e.g. varying proportions of humic substances in the soil or inner plant compartments (lignin) and wax proportions in the plant, other natural matrix components);

- long exposure in the field under different climatic influences (e.g. frost, heat, rainfall, UV radiation). 
Contacts between the pollutants and the matrix in such samples can (for example in contrast to studies with spiked soil material) continue for a long time, lasting months or even years. Depending on the level of organic substances, this can lead, for individual substances in the long term, to strong interactions in soils or plants and thus to bound residues $/ 39,40 /$. Thus, when optimizing a method, these various criteria can only be taken into account in labs where the corresponding samples have been analyzed and which have experience of the problems involved (e.g. site selection, sampling, processing of diverse matrices, analysis).

\subsection{Aims of methodological improvements}

Methodological improvements are also absolutely necessary so that important ecotoxicological processes can be observed more closely than before. One important step in this respect was the fractionation of the plant sample material $/ 34 /$. Therefore we first performed the extractive separation (dichlormethane) of pine needles and leaves taken from deciduous trees into the fractions wax layer and inner needle/leaf $/ 11,35 /$.

This operational separation enabled the pollutants bioavailability to be described, while the processing of the two separate fractions (thanks to the division of lipid-rich plant components) improved cleanup and analysis (Figure 10) $/ 41 /$. This extractive fractionation was preceded by investigations into the pollutant content in the wax fraction as a function of the extraction time (Figure 11) /34/.

These methodological improvements resulting from the described compartment-related separation improved understanding of special processes such as uptake, bioavailability and the effect of anthropogenic pollutants in plant compartments.

\subsection{Working hypothesis and the resulting work programme}

Our working hypothesis was that, with ASE, by optimizing the operating variables pressure, temperature and the polarity of the solvent (or mixtures thereof), it ought to be possible greatly to improve the extraction efficiency. To achieve these working aims, a suitable investigation strategy had to be drawn up. Priority was given to avoiding interference factors when dealing with such complicated matrices. In doing so, the following points were observed: 
1. No certified or spiked sample material would be used, but instead real samples, i.e. samples which have aged in the field.

2. Usage of moss samples for basic investigations; relatively uncomplicated matrix; good quality of cleanup.

3. Usage of a large pool of mixed samples from a single location; optimum comparability of the extracted samples - low relative standard deviation (RSD).

4. Findings obtained for mosses would be transferred to the difficult pine needle plant matrix.

5. Usage of a mixed soil sample pool from two local sites, which differ significantly in soil characteristics (soil parameters, humic substances) and contamination levels.

6. Performance of three or four parallel extractions for temperaturedependent extractions of plant and soil samples.

7. Usage of optimized extraction parameters for the extraction of real pine needle and soil samples.

8. Comparison of ASE extraction efficiency with USE (plant samples) and SOX (soil samples).

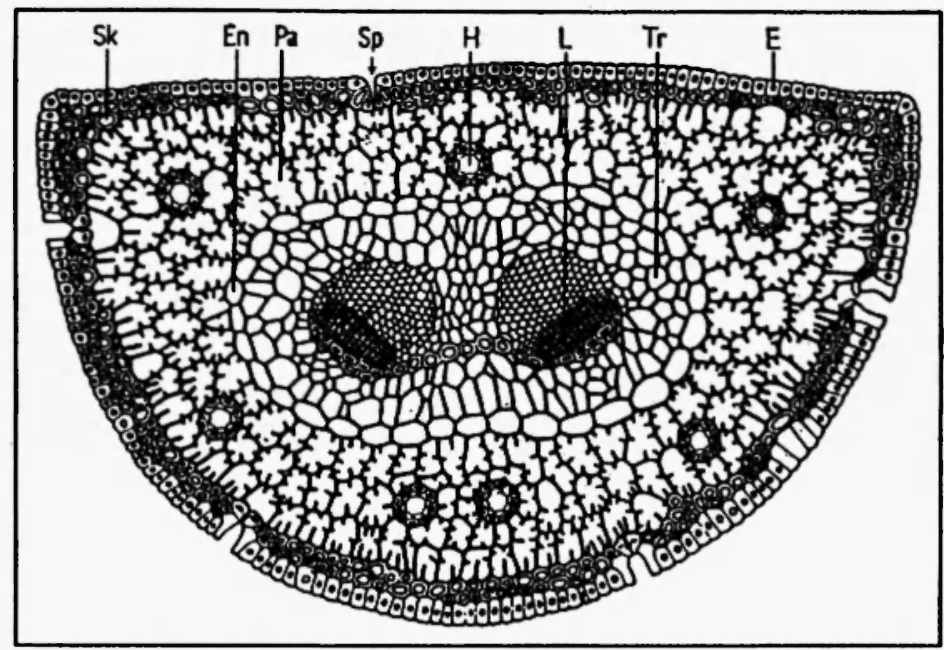

Fig. 10: Cross section through the pine needle; Sk hypodermale sclerenchym; En endodermis; $\mathrm{Pa}$ assimilation parenchyme; $\mathrm{Sp}$ stomata; $H$ Resin ducts; $L$ vascular bundle; Tr transfusion tissue; $E$ epidermis (40:1, R.v. Wettstein) 


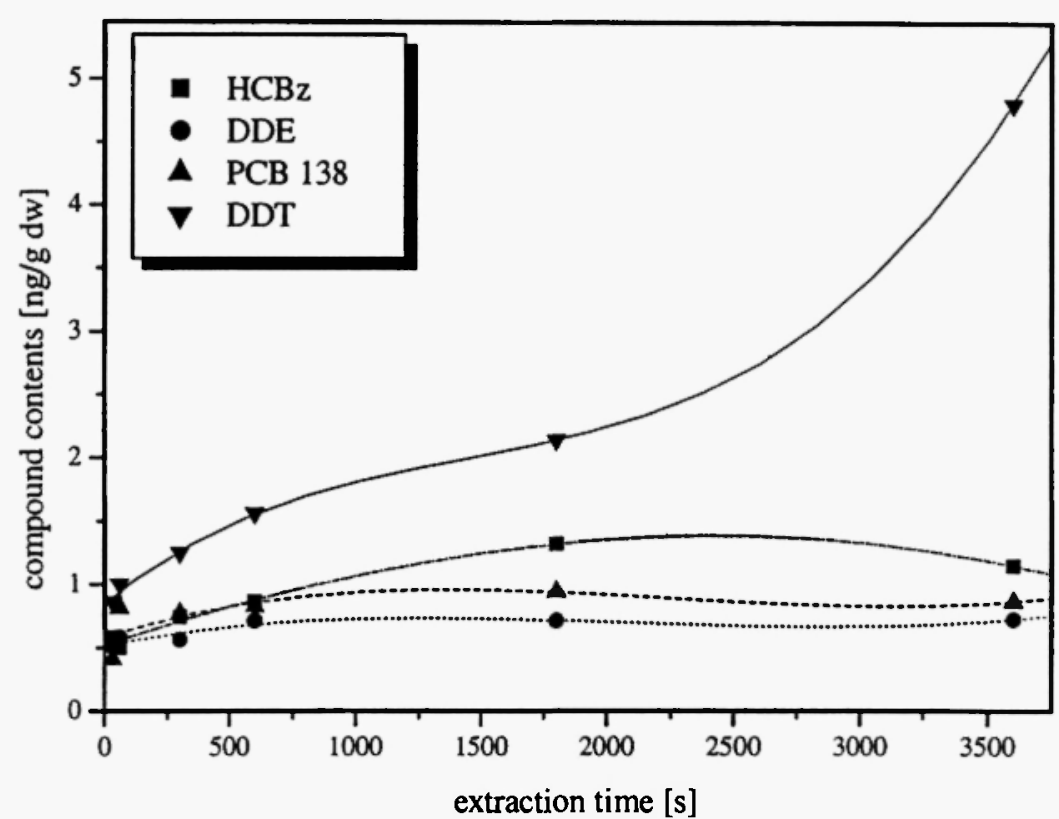

Fig. 11: Compound Content in the Wax Layer as a Function of Extraction Time. The Four Series of Data and Associated Fitted Curves Refer to the Compounds HCB, DDT, DDE, and PCB 128, Respectively

\section{EXPERIMENTAL PART}

\subsection{Sampling: plant material}

The plant material used consists of moss samples of the species Pleurozium schreberi and 2-year-old pine needles of the species Pinus sylvestris $\mathrm{L}$.

The moss samples were collected at biomonitoring sites in central Germany (Leipzig-Halle region) and mixed for temperature- and solventdependent investigations. After sampling, the mosses were kept cool during transport and then frozen at $-20^{\circ} \mathrm{C}$ until further preparation. The water content of mosses was determined by drying separate subsamples at $85^{\circ} \mathrm{C}$ until the constant final dry weight (dw) had been reached (ca. 80 wt \% water).

The pine needles were collected at nine locations in southern Russia (between the Caspian Sea and the Black Sea) and in the Leipzig-Halle region. 
The investigations were performed on needles from up to three individual trees per site. After sampling, the needles were kept cool during transport and then frozen at $-20^{\circ} \mathrm{C}$ until further preparation. The water content of the needles was determined by drying separate subsamples at $85{ }^{\circ} \mathrm{C}$ until the constant final $d w$ has been reached (ca. 55-60 wt \% water).

\subsection{Sampling: soil material}

Topsoil samples $(0-5 \mathrm{~cm})$ were taken in Leipzig-Halle region (sites: Hettstedt and Rosa) and at nine locations in southern Russia. The soil was kept cool during transport to the laboratory, where it was air-dried for $24 \mathrm{~h}$ at room temperature. The soil was frozen at $-80^{\circ} \mathrm{C}$ until further preparation.

\subsection{Standards, materials, and solvents}

The extracts were quantified using $p, p^{\prime}-\mathrm{DDT}, p, p^{\prime}-\mathrm{DDE}, \gamma-\mathrm{HCH}$, the internal standard mixture containing a ${ }^{13} \mathrm{C}$-labeled chlorobenzene cocktail (EM-1725-A), PCB 28 (EC-1413), PCB 153 (EC-1406) and the deuterated PAH Surrogate cocktail (ES-2044). These standards were supplied by Promochem (Wesel, Germany). All solvents (n-hexane, dichloromethane, toluene, acetone, methanol, diethyl ether) used were of analytical grade (Merck GmbH; Germany). For cleanup columns $40 \mathrm{~g}$ Florisil ${ }^{\boxplus} 60-100$ mesh (Promochem; Wesel, Germany) was conditioned with the double volume of solvents methanol and dichloromethane. After drying at $100-120^{\circ} \mathrm{C}$ in a drying cupboard it was activated under nitrogen for $4 \mathrm{~h}$ at $180^{\circ} \mathrm{C}$.

\subsection{ASE: general conditions}

Extractions of air-dried plant samples corresponding to $10 \mathrm{~g}$ fresh weight or soil samples were carried out using $33 \mathrm{~mL}$ stainless steel vessels of a Dionex ASE 200 (Dionex GmbH, Idstein, Germany). Pine needle samples were divided beforehand by extraction with dichloromethane (USE) into the wax and the inner needle fraction. For further ASE investigations the wax fraction was adsorbed on sea sand. The sample material was given in the extraction cell and the stagnant volume of the cell was filled up with hydro matrix (Bulk ISOLUTE ${ }^{\infty}$ Sorbent, Isolute HM-N; International Sorbent Technology GmbH, Germany) and a mixture of $\sim 10 \mathrm{~g}$ Florisil ${ }^{\star} / \mathrm{Al}_{2} \mathrm{O}_{3} 2: 1$ (as precleanup). So that the stagnant volume would be at the bottom end, the cell 
was inverted. The extraction step consists of a heating phase of $5 \mathrm{~min}(8 \mathrm{~min}$ at $180^{\circ} \mathrm{C}$ ) and three $10-\mathrm{min}$ static cycles. It was extracted for each cycle with $\sim 20 \mathrm{~mL}$ solvent and at the end of the extraction rinsed with $\sim 2 \mathrm{~mL}$ of the same solvent. The time for rinsing (nitrogen) being $120 \mathrm{~s}$.

\subsection{USE: general conditions}

The plant samples (air-dried material corresponding to $10 \mathrm{~g}$ fresh weight) were shredded with the Ultra Turrax T25 (IKA-Labortechnik, Janke \& Kunkel; Staufen, Germany). Extractions (bath sonication, cooling water was circulated through the bath) were carried out using a Transsonic Digital S (Elma ${ }^{\oplus}$, HF $40 \mathrm{kHz}, 400 \mathrm{~W}$; Singen, Germany). Extraction time was $10 \mathrm{~min}$ with $\mathrm{CH}_{2} \mathrm{Cl}_{2}$ for the separation of the wax layer and $3 \times 10$ min with $\mathrm{n}$ hexane/ $\mathrm{CH}_{2} \mathrm{Cl}_{2} 8: 2$ for the extraction of the inner needle fraction or mosses.

Extractions of soil samples (bath sonication, cooling water was circulated through the bath, bath temperature $15-20^{\circ} \mathrm{C}$ ) were carried out using a Sonorex Super RK 255H (Brandelin electronic, HF $35 \mathrm{kHz}$, power $320 \mathrm{~W}$; Berlin, Germany). Ten gram samples of air-dried soils ( $\sim 24 \mathrm{~h}$ until a constant final weight had been reached) were extracted $3 \times 10$ min with $n$-hexane or $n$ hexane $/ \mathrm{CH}_{2} \mathrm{Cl}_{2}$ 1:1.

\subsection{SOX: general conditions}

Ten gram samples of air-dried soils were extracted with $150 \mathrm{~mL}$ portions of toluene in a DET 5 Soxhlet unit (Behr Labor-Technik GmbH, Dusseldorf, Germany) for $24 \mathrm{~h}$.

\subsection{Cleanup}

After applying extraction procedures (ASE, Soxhlet or USE), internal standard solutions were added. The extracted phases were concentrated to 2 $\mathrm{mL}$ by means of rotovapor. This concentrated solution was transferred to column 1 (diameter $1 \mathrm{~cm}$, length $20 \mathrm{~cm}$ ) containing $\sim 15 \mathrm{~g}$ of deactivated Florisil (4\% water) to separate out the hydrophylic plant compounds. It was eluted with $160 \mathrm{~mL}$-hexane/dichloromethane 1:1. Only for plant samples, the first $60 \mathrm{~mL}$ of the eluate, containing the principal quantity of the pollutants, was transferred to column 2 (diameter $0.5 \mathrm{~cm}$, length $20 \mathrm{~cm}$ ) containing $-3.5 \mathrm{~g}$ of activated Florisil to separate out lipophilic plant 
compounds. Column 2 was eluted with $60 \mathrm{~mL}$ of $\mathrm{n}$-hexane/dichloromethane $1: 1$. The eluates were concentrated to dryness, the residue being extracted three times with $2 \mathrm{~mL}$ diethyl ether, transferred to a vial, evaporated to dryness under nitrogen and dissolved in $200 \mu \mathrm{L}$ of toluene.

\subsection{Analysis}

GC-MS analysis was carried out using a Hewlett Packard (HP) 5971 mass spectrometer in SIM-mode coupled with an HP 5890 capillary column gas chromatograph equipped with an HP 7673 auto sampler. An HP ultra 2 capillary column $25 \mathrm{~m} \times 0.32 \mathrm{~mm}$ i.d. $\times 0.52 \mu \mathrm{m}$ film thickness was used. The carrier gas was helium (purity 5.0; Linde $\mathrm{GmbH}$, Höllkriegelskreuth, Germany). One microliter of sample was injected in the splitless mode at $0.75 \mathrm{~min}$. The temperature program was as follows: initial temperature $60^{\circ} \mathrm{C}$ held for $1 \mathrm{~min}$, followed by a $10^{\circ} \mathrm{C} \mathrm{min} \mathrm{m}^{-1}$ ascent up to $260^{\circ} \mathrm{C}$, maintained for $1 \mathrm{~min}$. The analytical parameters such as detection limit, identification and quantification of the POPs were determined using internal standard solutions. Recovery in the soil matrix for organochlorines ranged from $90 \%$ for $\gamma-\mathrm{HCH}$ to $97 \%$ for PCB 153 . PAH recovery was $80-90 \%$ for pyrene, phenanthrene, anthracene and fluoranthene, and $50-75 \%$ for benzo[ $[a]$ pyrene.

\section{OPTIMIZED EXTRACTION OF PLANT SAMPLES}

\subsection{ASE in environmental analysis}

The main area in which ASE is currently used is environmental analysis. Following the introduction of ASE, investigations were first carried out to establish whether this new method guarantees comparable results with accepted techniques specified in standardized methods $138 \%$. One of these techniques already established in environmental analysis is Soxtec. The findings of these experiments formed the basis for the development of USEPA Method 3545 for the extraction of semivolatile alkaline, neutral and acid compounds as well as pesticides, herbicides and polychlorinated biphenyls. The recovery rates of ASE compared to Soxtec were for the above-described alkaline, neutral and acid organic compounds on average as follows: for sand samples $102.1 \%$, for loamy soil $98.7 \%$ and for clay $96.8 \%$; for chlorinated substances: for sand samples $96.8 \%$, for loam $99.1 \%$, and for clay $96.0 \%$. 
This demonstrates the universal applicability of this method in the lab. Moreover, no attempt was made to optimize the extraction parameters to increase extraction efficiency. We believe that ASE harbours great potential for selective extraction by choosing suitable operational variables. This is naturally related to the strong matrix dependency of extraction efficiency. On the other hand, this also means that cleanup processes need to be improved or new procedures developed in order to remove possibly numerous interference components from the sample matrix.

\subsection{Application notes for soils - starting point of initial tests}

As no ASE instructions existed for the plant matrix we started our investigations with the conditions of Dionex's application notes for soil $\left(100^{\circ} \mathrm{C}\right.$, n-hexane/acetone $\left.1: 1\right) / 19,42 /$. Initial studies of the extraction of POPs and PAHs from pine needles using ASE resulted in an extraction efficiency which was poorer for almost all pollutant classes tested than conventional USE (Figure 12). The volatile hexachlorobenzene and lowchlorinated PCBs were not detected at all by ASE. However, ASE was somewhat better at extracting the DDT metabolites DDE and DDD /43/.

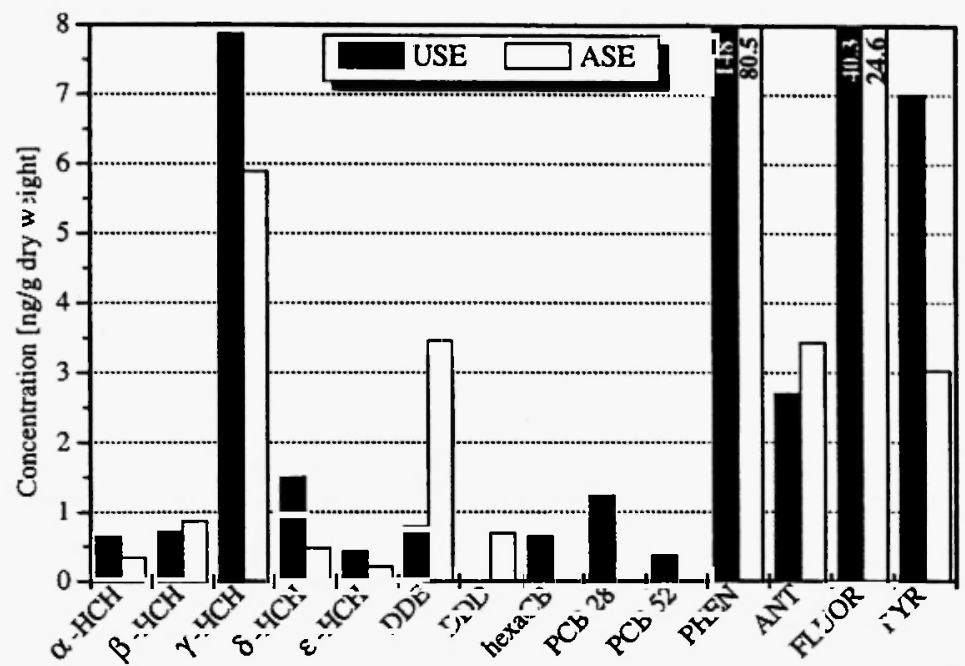

Fig. 12: Comparison between ASE and USE using mixed samples of pine needles (region Leipzig-Halle). A mixture of acetone/n-hexan (1:1 v/v) was used as extractant. Not detectable: DDT, 1,2,3,4-tetraCB, pentaCB, PCB 101, PCB 138, PCB 153, PCB 180 and BaP 
One reason for the generally lower needle concentrations detected by ASE is thought to be the polar proportion of acetone in the extractant. In the complicated plant matrix, this also results in the higher extraction of polar substances (e.g. chlorophyll and conjugates), which interfere with cleanup and analysis. One advantage already mentioned of ASE is that in addition to pressure and temperature, the polarity of the extractant can be varied over a wide range and can hence be geared to the matrix and analyte palette.

\subsection{Influence on the extraction efficiency}

\subsubsection{Influence of extraction pressure}

The extraction pressure keeps the solvent (or mixture of solvents) at temperatures higher than the boiling point in the liquid state required for extraction $/ 2 /$. This was the case at a pressure of $15 \mathrm{MPa}$ for all the solvents we used. Since reducing the pressure to $10 \mathrm{MPa}$ or raising it to $20 \mathrm{MPa}$ did not affect the extraction efficiency $/ 44 /$ whatsoever, all the extraction processes (including for soil) were performed at $15 \mathrm{MPa}$.

\subsubsection{Influence of solvent}

In previous ASE applications, the $n$-hexane/acetone solvent mixture usually proved to be a suitable extractant for persistent organic compounds. However, using acetone/dichlormethane and toluene with ASE also produced similar values for PAHs to SOX $/ 4 /$.

Of a large number of solvents and solvent mixtures of graded polarity ( $n$ hexane, cyclohexane, dichlormethane, methanol, acetone and mixtures thereof), the solvents $n$-hexane and toluene proved the most suitable. Using $\mathrm{n}$-hexane reduces the quantities of interfering polar matrix components simultaneously extracted. Although toluene produces similar results (Table 3 ), it was not used for further experiments owing to the greater time required to process the extracts (because of the higher boiling point required). However, it should always be regarded as an alternative for other sites and varying matrices, and tested accordingly.

\subsubsection{Influence of extraction temperature}

The extraction temperature ought via the diffusion coefficient to have a distinct influence on the extraction kinetic and therefore also on the extraction efficiency $/ 2 \%$. Initial studies of moss samples at an extraction temperature of just $100^{\circ} \mathrm{C}$ using $\mathrm{n}$-hexane as the solvent produced much 
Table 3

Extraction Efficiencies for Pollutant Groups Depending on the Extraction Method and Solvent

\begin{tabular}{|c|c|c|c|c|c|}
\hline compd & $\mathbf{U S E}^{\mathbf{2}}$ & $\begin{array}{c}\mathbf{A S E}^{\mathbf{b}} \\
\text { n-hexane }\end{array}$ & $\begin{array}{l}\text { RSD } \\
{[\%]}\end{array}$ & $\begin{array}{c}\mathbf{A S E}^{\mathbf{b}} \\
\text { toluene }\end{array}$ & RSD [\%] \\
\hline$\alpha-\mathrm{HCH}$ & 0.58 & 0.61 & 7.2 & 1.06 & 4.7 \\
\hline$\beta-\mathrm{HCH}$ & 0.86 & 0.70 & 11.3 & 1.55 & 1.4 \\
\hline$\gamma-\mathrm{HCH}$ & 1.90 & 6.03 & 7.4 & 4.91 & 7.1 \\
\hline$\delta$-HCH & nd & 1.67 & 2.8 & 1.67 & 20.2 \\
\hline$\varepsilon-\mathrm{HCH}$ & nd & 1.97 & 43.2 & 1.02 & 46.6 \\
\hline$\Sigma$ HCHs & 3.34 & 11.0 & 14.4 & 10.2 & 16.0 \\
\hline DDT & 0.11 & 1.99 & 9.3 & 2.24 & 10.7 \\
\hline DDE & 0.95 & 3.61 & 7.8 & 3.78 & 1.3 \\
\hline DDD & nd & 1.25 & 32.6 & 0.43 & 66.3 \\
\hline$\Sigma$ DDX & 1.06 & 6.85 & 16.6 & 6.45 & 26.1 \\
\hline TCBz & 0.26 & nd & - & 0.38 & 0,5 \\
\hline PCBz & nd & 0.09 & 20.5 & 0.12 & 17.9 \\
\hline $\mathrm{HCBz}$ & nd & 0.10 & 18.4 & 0.15 & 7.2 \\
\hline$\Sigma \mathrm{Cl}-\mathrm{Bz}$ & 0.26 & 0.19 & 19.5 & 0.65 & 8.5 \\
\hline PCB 28 & 0.12 & 0.70 & 14.3 & 0.56 & 2.2 \\
\hline PCB 52 & 1.34 & 1.00 & 11.2 & 0.83 & 1.9 \\
\hline PCB 101 & 0.68 & 0.33 & 7.3 & 0.48 & 6.4 \\
\hline PCB 138 & nd & 0.09 & 44.6 & 0.18 & 1.2 \\
\hline PCB 153 & 0.61 & 0.11 & 11.5 & 0.12 & 16.6 \\
\hline PCB 180 & nd & nd & - & nd & - \\
\hline$\Sigma$ PCB & 2.75 & 2.23 & 17.8 & 2.17 & 5.7 \\
\hline Phen & 38.1 & 56.5 & 13.5 & 61.9 & 0.5 \\
\hline Ant & 1.57 & 8.71 & 10.1 & 5.00 & 1.4 \\
\hline Fluor & 21.7 & 47.5 & 9.7 & 46.1 & 0.5 \\
\hline Pyr & 6.82 & 12.7 & 12.7 & 12.8 & 1.5 \\
\hline $\mathrm{BaP}$ & 3.12 & 5.32 & 9.4 & 3.40 & 6.8 \\
\hline$\Sigma$ PAHs & 71.3 & 133 & 11.1 & 129 & 2.1 \\
\hline
\end{tabular}

Concentrations are given as ng/g of dry weight (nd, not detectable). "two extraction steps: first with n-hexane and second with dichloromethane. triple determinations for each solvent; Extraction temperature $100^{\circ} \mathrm{C}$. 
greater pollutant yields than USE - about $200 \%$ for $\mathrm{HCHs}, 190 \%$ for DDX, and $120 \%$ for PAHs.

To systematically test the influence of temperature, triple determinations of moss samples from one location were carried out at a constant pressure of $15 \mathrm{MPa}$ at $20^{\circ} \mathrm{C}$ steps between 20 and $140^{\circ} \mathrm{C}$ as well as at $170^{\circ} \mathrm{C} / 43 /$. Conclusions for the five groups of pollutants can be derived from Figure 13. When using n-hexane as the solvent, and with a warm-up phase of $5 \mathrm{~min}$ followed by $3 \times 10$ min static extraction, the best temperature for $\mathrm{HCHs}$, DDX, chlorobenzenes and the most PAHs is $120^{\circ} \mathrm{C}$. By contrast, the most favorable extraction conditions for PCBs and benzo(a)pyrene occur at a temperature of $40^{\circ} \mathrm{C}$. A large increase in the extraction yield of up to $26 \%$ in individual cases occurred for PAHs above all between 100 and $120^{\circ} \mathrm{C}$. The only exceptions in this respect were DDE and $\delta-\mathrm{HCH}$, whose extraction

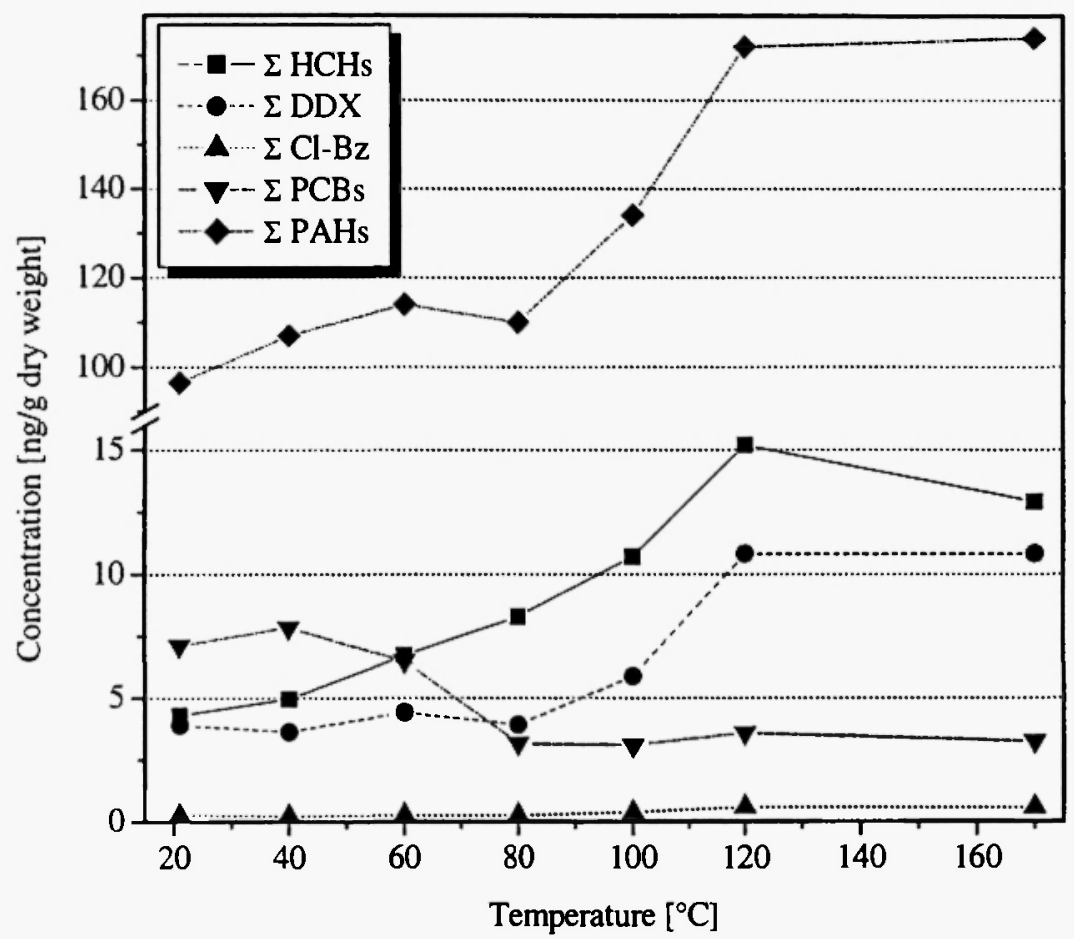

Fig. 13: Sum Curves for Extraction efficiency of different pollutant groups from mosses (Pleurozium schreberi) in dependence on the extraction temperature using ASE (solvent is $n$-hexane). 
yields at $170{ }^{\circ} \mathrm{C}$ rose by around $10 \%$ and $80 \%$ respectively compared to 120 ${ }^{\circ} \mathrm{C}$. However, an extraction temperature of $170^{\circ} \mathrm{C}$ is not recommended, as very large quantities of matrix components are also extracted. Even following cleanup, this resulted in large amounts of impurities in the extracts and consequently considerably interferences with the overall analysis. It is therefore recommended that two successive extraction steps be carried out at 40 and $120^{\circ} \mathrm{C}$ using $\mathrm{n}$-hexane or toluene as the solvent for the simultaneous extraction of pollutants investigated from a plant matrix. Filling up the dead volume of the cell with a mixture of Florisil $/ / \mathrm{Al}_{2} \mathrm{O}_{3}$ to precleanup needle extracts was found to have a positive effect.

\subsection{Comparison between ASE and USE using real plant samples}

The parameters optimized for the moss matrix were transferred to the extraction of real pine needle samples from areas in southern Russia between the Caspian and Black Seas, which had been exposed to multiple external pollution for a long time. The selected locations differ greatly in terms of the degree of contamination. The extracts were in some cases very oily. Before determination of the pollutants, the samples were divided into the compartments wax layer and internal needle as described above in 2.2 .

Table 4 lists the results of triple determinations (three individual trees from one location) of the inner needle fraction at two different locations. In comparison with USE, extraction efficiency when using ASE was much higher - up to 1-2 orders of magnitude for the PCBs and PAHs $143 /$. The relative standard deviation, which is generally $20-60 \%$ at each location $/ 33 /$, was in an excellent range for the plant matrix when ASE was used (5-30\%).

The differences between the two locations were especially apparent upon direct comparison with USE. Whereas at site 2 the extracts from all three trees obtained using ASE could be analysed, extraction with USE only produced measurable values for all three trees for HCHs and PAHs. The reason for this was the insufficient separation between analyte and matrix. This was ascertained by subsequent ASE of the Florisil ${ }^{\star}$ used as column material for cleanup, whereupon the quantities of pollutant not detected after USE were detected in the amounts expected. These findings were confirmed with USE/ASE comparisons of needle samples from other areas in southern Russia (Table 5).

The wax layer was a less complicated matrix for analytical investigations than the inner needle. As expected, the wax layer did not permit such high 
Table 4

Extraction of SOCs with USE and ASE from the Inner Pine Needle Fraction at Three Trees of One Site

\begin{tabular}{|c|c|c|c|c|c|c|c|c|}
\hline \multirow[b]{3}{*}{ compound } & \multicolumn{4}{|c|}{ site $^{2} 1$} & \multicolumn{4}{|c|}{$\operatorname{site}^{2} 2$} \\
\hline & \multicolumn{2}{|c|}{$\mathbf{U S E}^{\mathbf{b}}$} & \multicolumn{2}{|c|}{$\mathbf{A S E} \mathbf{E}^{\mathbf{b}}$} & \multicolumn{2}{|c|}{$\mathbf{U S E}^{\mathbf{b}}$} & \multicolumn{2}{|c|}{$\mathbf{A S E} \mathbf{E}^{\mathbf{b}}$} \\
\hline & mean & $\begin{array}{l}\text { RSD } \\
(\%)\end{array}$ & mean & $\begin{array}{l}\text { RSD } \\
(\%)\end{array}$ & mean & $\begin{array}{l}\text { RSD } \\
(\%)\end{array}$ & mean & $\begin{array}{l}\text { RSD } \\
(\%)\end{array}$ \\
\hline$\alpha-\mathrm{HCH}$ & 0.19 & 42.1 & 6.83 & 6.5 & 3.18 & 0.6 & 2.68 & 27.2 \\
\hline$\beta-\mathrm{HCH}$ & 0.04 & 25.0 & 6.61 & 8.9 & 0.12 & 25.0 & 2.48 & 25.4 \\
\hline$\gamma-\mathrm{HCH}$ & 0.12 & 15.4 & 31.5 & 18.6 & 0.80 & 7.5 & 3.55 & 24.5 \\
\hline$\delta-\mathrm{HCH}$ & nd & & 0.84 & 11.8 & 1.15 & 13.0 & 1.94 & 42.8 \\
\hline$\varepsilon-\mathrm{HCH}$ & nd & & 6.96 & 25.7 & 0.43 & 9.3 & 0.97 & 18.6 \\
\hline sum/av RSD (\%) & 0.35 & 27.5 & 52.7 & 14.3 & 5.68 & 11.1 & 11.6 & 27.7 \\
\hline DDT & 0.14 & 21.4 & 0.90 & 15.4 & $0.17^{\mathrm{c}}$ & & 0.56 & 3.6 \\
\hline DDE & nd & & 2.01 & 71.2 & 0.63 & 1.6 & 0.57 & 47.4 \\
\hline DDD & nd & & 1.28 & 12.8 & $0.08^{c}$ & & 1.56 & 35.3 \\
\hline sum/av RSD (\%) & 0.14 & 21.4 & 4.19 & 33.1 & 0.88 & & 2.69 & 28.7 \\
\hline tetraCB & nd & & nd & & nd & & 0.26 & 9.8 \\
\hline hexaCB & nd & & 0.38 & 3.7 & $0.22^{c}$ & & 0.52 & 19.2 \\
\hline sum/av RSD (\%) & & & 0.38 & 3.7 & 0.22 & & 0.78 & 14.5 \\
\hline PCB 28 & nd & & 40.0 & 3.2 & $0.38^{c}$ & & 60.7 & 14.2 \\
\hline PCB 52 & nd & & 3.83 & 4.5 & $0.22^{\mathrm{c}}$ & & 0.97 & 21.6 \\
\hline PCB 101 & nd & & 11.3 & 8.4 & $0.19^{c}$ & & 2.81 & 17.1 \\
\hline PCB 138 & nd & & 8.00 & 2.8 & $0.10^{c}$ & & 2.01 & 29.9 \\
\hline PCB 153 & nd & & 8.31 & 7.0 & $0.10^{c}$ & & 2.14 & 22.0 \\
\hline PCB 180 & nd & & 2.46 & 5.9 & nd & & 1.39 & 16.5 \\
\hline sum/av RSD (\%) & & & 73.6 & 5.3 & 0.99 & & 70.0 & 20.2 \\
\hline PHEN & 0.39 & 15.4 & 83.5 & 6.5 & 17.6 & 4.8 & 52.6 & 20.2 \\
\hline ANT & 0.04 & 50.0 & 6.48 & 8.4 & 1.84 & 1.6 & 4.11 & 20.9 \\
\hline FLUOR & 0.38 & 26.3 & 34.6 & 9.2 & 11.6 & 2.8 & 27.6 & 14.2 \\
\hline PYR & 0.14 & 35.7 & 8.68 & 6.1 & 7.68 & 0.4 & 12.3 & 26.2 \\
\hline $\mathrm{BaP}$ & nd & & 0.84 & 36.4 & $0.30^{c}$ & & 0.27 & 51.9 \\
\hline sum/av RSD (\%) & 1.31 & 31.9 & 134 & 13.3 & 39.0 & 2.4 & 96.9 & 26.7 \\
\hline
\end{tabular}

Concentration is ng/g of dry mass, (nd, not detectable). Solvent is $n$-hexane.

"Sites in southern Russia. 'Number of the replicated investigations is three.

'Only one measuring value because of insufficient extraction efficiency 
Table 5

Comparison of the Extraction Methods USE and ASE for POPs and PAHs from the Inner Pine Needle Fraction

\begin{tabular}{|c|c|c|c|c|c|c|c|c|}
\hline \multirow[b]{3}{*}{ compd } & \multicolumn{8}{|c|}{ site" } \\
\hline & \multicolumn{2}{|c|}{1} & \multicolumn{2}{|c|}{2} & \multicolumn{2}{|c|}{3} & \multicolumn{2}{|c|}{4} \\
\hline & USE & ASE & USE & ASE & USE & ASE & USE & ASE \\
\hline$\alpha-H C H$ & 0.38 & 5.61 & 1.36 & 0.96 & 0.29 & 4.43 & 0.84 & 17.5 \\
\hline$\beta-\mathrm{HCH}$ & 0.44 & 0.49 & 0.20 & 1.76 & nd & 9.76 & 0.39 & 7.61 \\
\hline$\gamma-\mathrm{HCH}$ & 5.02 & 2.91 & 0.56 & 2.30 & 0.55 & 3.29 & 1.19 & 22.9 \\
\hline$\delta-\mathrm{HCH}$ & 2.05 & 0.41 & 0.25 & 0.76 & 0.28 & 1.27 & 0.56 & 1.65 \\
\hline$\varepsilon-\mathrm{HCH}$ & 0.39 & 0.27 & 0.16 & 0.47 & 0.13 & 3.55 & 0.25 & 1.11 \\
\hline sum & 8.28 & 9.69 & 2.53 & 6.25 & 1.25 & 22.3 & 3.23 & 50.8 \\
\hline DDT & 0.46 & 0.40 & 0.82 & 0.19 & 0.90 & 1.23 & 0.17 & 2.37 \\
\hline DDE & & 0.63 & 0.45 & 0.33 & 0.13 & 0.61 & 0.11 & 2.64 \\
\hline DDD & 0.30 & 0.11 & 0.05 & 1.03 & 0.03 & 0.07 & 0.19 & 0.98 \\
\hline sum & 0.76 & 1.14 & 1.32 & 1.55 & 1.06 & 1.91 & 0.47 & 5.99 \\
\hline tetraCB & nd & 0.30 & nd & 0.15 & nd & 0.02 & nd & nd \\
\hline hexaCB & 0.26 & 0.39 & nd & 0.37 & nd & 0.37 & nd & 0.62 \\
\hline sum & 0.26 & 0.42 & & 0.52 & & 0.39 & & \\
\hline PCB 28 & 0.21 & 39.5 & 0.10 & 49,7 & nd & 12.9 & 0.24 & 38.5 \\
\hline PCB 52 & 0.18 & 0.30 & 0.09 & 1.05 & nd & 0.18 & 0.14 & 4.48 \\
\hline PCB 101 & 0.49 & 0.27 & 0.22 & 2.89 & nd & 0.22 & 0.27 & 12.6 \\
\hline PCB 138 & nd & 0.24 & nd & 2.07 & nd & 0.24 & nd & 9.28 \\
\hline PCB 153 & nd & 0.29 & 0.19 & 2.14 & nd & 0.33 & nd & 9.48 \\
\hline PCB 180 & nd & nd & nd & nd & nd & 1.91 & nd & 3.40 \\
\hline sum & 0.88 & 40.6 & 0.6 & 57.9 & & 15.8 & 0.65 & 77.7 \\
\hline PHEN & 15.9 & 31.2 & 11.9 & 65.6 & 2.12 & 19.8 & 7.99 & 124 \\
\hline ANT & 4.18 & 2.04 & 2.43 & 2.83 & 0.71 & 0.55 & 0.72 & 9,69 \\
\hline FLUOR & 3.32 & 11.2 & 12.2 & 21.2 & 1.99 & 10.2 & 1.80 & 38.7 \\
\hline PYR & 0.90 & 3.99 & 22.3 & 6.85 & 6.25 & 1.76 & 0.18 & 9.60 \\
\hline $\mathrm{BaP}$ & 0.53 & 0.38 & 0.26 & 0.28 & 1.15 & 0.31 & nd & nd \\
\hline sum & 24.8 & 89.4 & 49.7 & 155 & 12.2 & 32.6 & 10.7 & 182 \\
\hline
\end{tabular}

Concentration is nanograms per gram of dry mass (nd, not detectable). Solvent is $n$-hexane. "Measuring values of one tree at differently polluted sites in southern Russia. 
increases in extraction yield as the inner needle fraction. Nevertheless, the results produced in this matrix with ASE were still remarkable, with extraction rates exceeding USE by on average up to one order of magnitude depending on the target substance (Figure 14). The pollutant levels measured in the wax layer were mostly below those in the inner needle. Comparing the pollutant groups, the greatest increases of extraction yield were found for PCBs and PAHs.

Comparable extractions of cells filled with sea sand (under the same conditions) were used to determine the blank value. Pollutant concentrations were not detectable.

\subsection{Summary: plant matrix}

The optimum extractant for POPs and PAHs from real plant samples is nhexane (toluene). Key temperatures exist at 40 and $120^{\circ} \mathrm{C}$, at which the highest extraction efficiency is achieved depending on the plant matrix, the degree of contamination and the pollutant group.

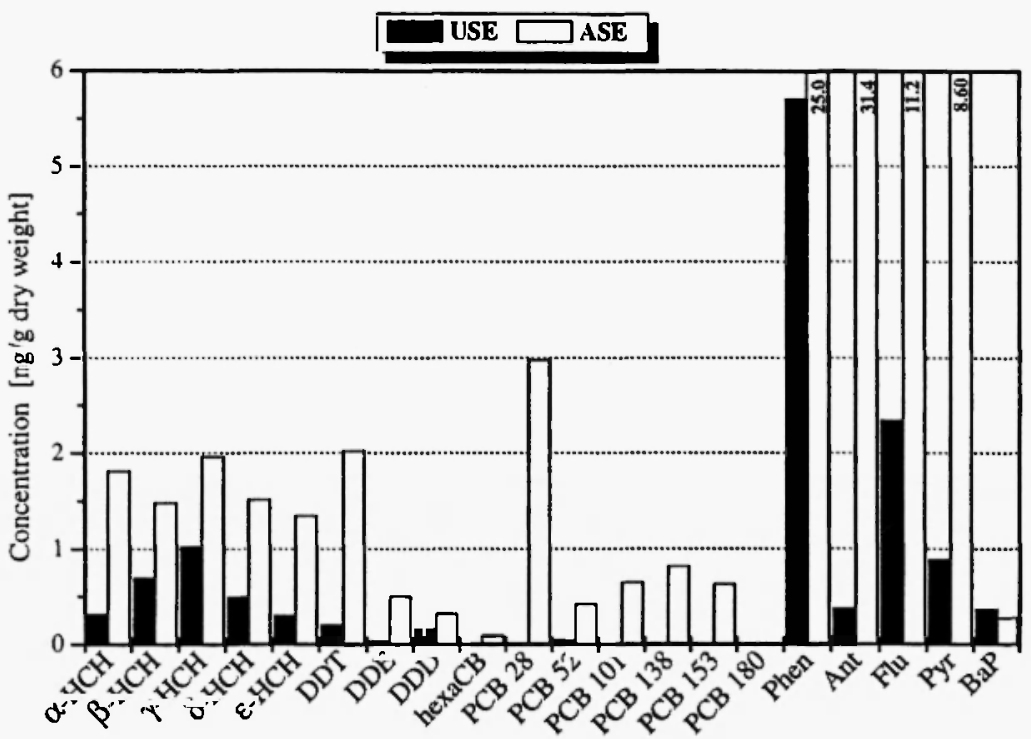

Fig. 14: Comparison between ASE and USE using mixed samples of the wax fraction of pine needles 
Extractions with the ASE 200 should be carried out at two temperature steps of 40 and $120^{\circ} \mathrm{C}$, a pressure of $15 \mathrm{MPa}$ and an extraction time of $3 \times 10$ min each.

Using ASE produced extraction efficiencies for POPs and PAHs up to two orders of magnitude higher than with USE depending on the composition of the sample material.

\section{OPTIMIZED EXTRACTION OF SOIL SAMPLES}

\subsection{Goal of the investigations}

The extraction efficiency of individual extraction methods for persistent organic pollutants (POPs) from soil material in particular also depends on physicochemical properties $/ 45$ / of the pollutants and on matrix factors such as the organic carbon content and other soil parameters (e.g. clay and oxides and hydroxides of inorganic elements), which can affect sorption and desorption, degradation and the formation of conjugates with the matrix. POPs persistence and lipophilic affinity lead to the accumulation and enrichment of these substances in soils with high organic contents $146,47 /$. Various correlations can be used to estimate the adsorption coefficient $K_{\text {oc }}$ $148,49 /$.

The ASE of POPs and PAHs from certified and spiked soils and sediments by other working groups produced recovery data (including precision and systematic deviation) comparable with those of conventional extraction methods $/ 4,9,20,44 /$, after we improved the extraction efficiency from the real contaminated biological matrix by a factor of up to 100 compared to USE by optimizing the operating variables solvent and temperature [see sections 4,5 ]. Our aim was to investigate real contaminated soil samples in view of the similar results.

\subsection{Influence of the solvent}

To test the influence of the solvent on extraction efficiency, ASE was compared with the traditional methods of USE and SOX using double and triple determinations of mixed samples from the site Rosa. The extraction temperatures initially used for ASE soil extractions were 40 and $120^{\circ} \mathrm{C}$, as in the previous studies involving plant material $/ 1,43 /$. All samples were 
extracted at a constant pressure of $15 \mathrm{MPa}$, as varying the pressure did not affect the results [see sub-section 4.3.1]. Comparisons between the methods used and the different solvents revealed that under these conditions, the best extraction yields for ASE were achieved with toluene as the extractant (Table 6). The largest increases compared to SOX were found for the compounds $\mathrm{HCHs}$ (around double) and the PAHs (approximately four-fold). By contrast, when the solvent combination $n$-hexane $/ \mathrm{CH}_{2} \mathrm{Cl}_{2}$ 1:1 was used, the extraction yields for organochlorines were actually higher with USE than with ASE. This indicates that the quality of the results largely depends on the extractant used.

\subsection{Comparison between ASE and Soxhlet using real soil samples}

ASE was compared with SOX by carrying out two extraction steps at 40 and $120^{\circ} \mathrm{C}$ at the nine contaminated sites in southern Russian with toluene as the extractant. With just a few exceptions (see Table 7: area Caucasus, site 2 for $\mathrm{HCHs}$ and PAHs), the extraction yields when using ASE were much greater than with SOX. The difference in efficiency between the two extraction methods at each site is expressed by the factor $f_{i}\left(f_{i}=\right.$ conc. pollutant group ASE/conc. pollutant group SOX). The extraction yields when using ASE were up to 10 times higher for $\mathrm{HCHs}$, up to 19 times higher for DDXs, up to 5 times higher for chlorobenzenes, and up to 24 times higher for PAHs. In many cases, PCBs could only be detected by ASE, not SOX. The degree of improvement in extraction efficiency largely depended on the site and hence on the soil composition and the degree of multiple pollution. These promising findings were the reason to explore thoroughly the temperature influence on the extraction efficiency.

\subsection{Influence of extraction temperature}

Table 8 and Figure 15 show the results of the extraction efficiency for ASE. They result from quadruple determinations (Hettstedt) and triple determinations (Rosa). Hettstedt is $70 \mathrm{~km}$ west of Leipzig, near local heavy metal plants used to smelt shredded copper cables until the mid-1990s. The smelting/combustion processes liberated organochlorines such as hexachlorobenzene, DDT and $\mathrm{HCH}$ (lindane) $/ 50 /$, and soil in the area contains highly enriched levels of organic compounds. Rosa is located $30 \mathrm{~km}$ north of Leipzig in a pine forest area with predominantly sandy soil. The 


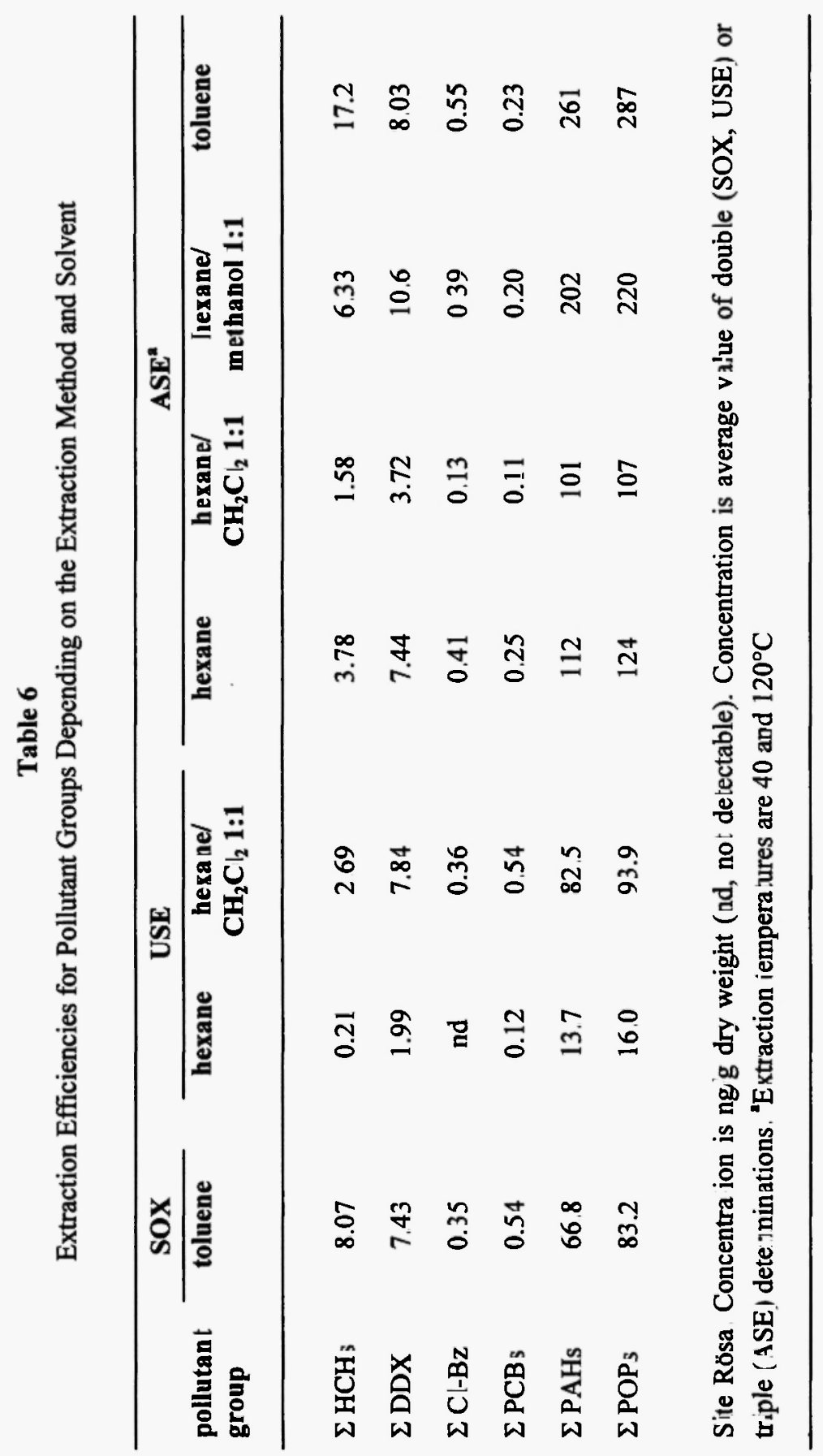




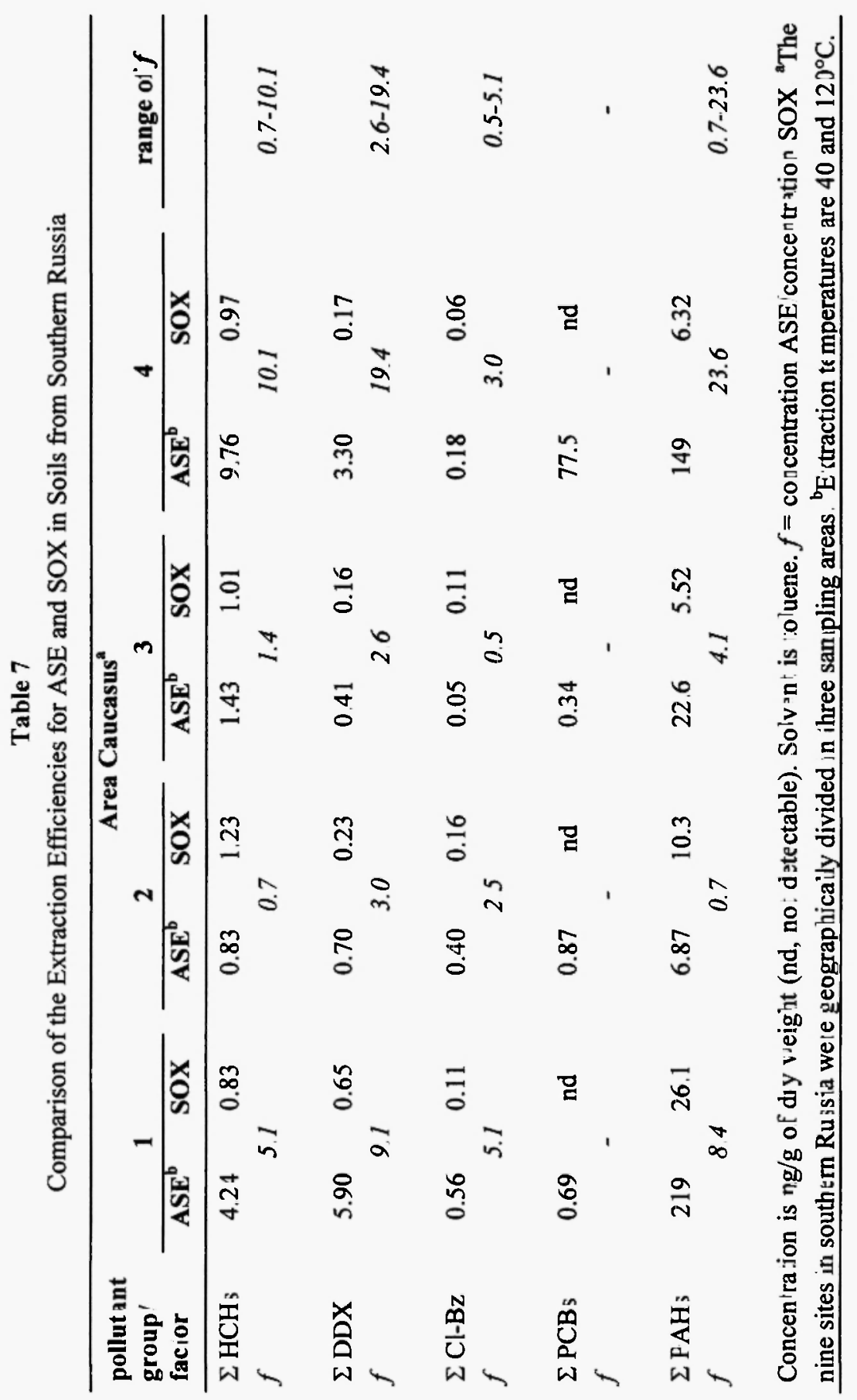




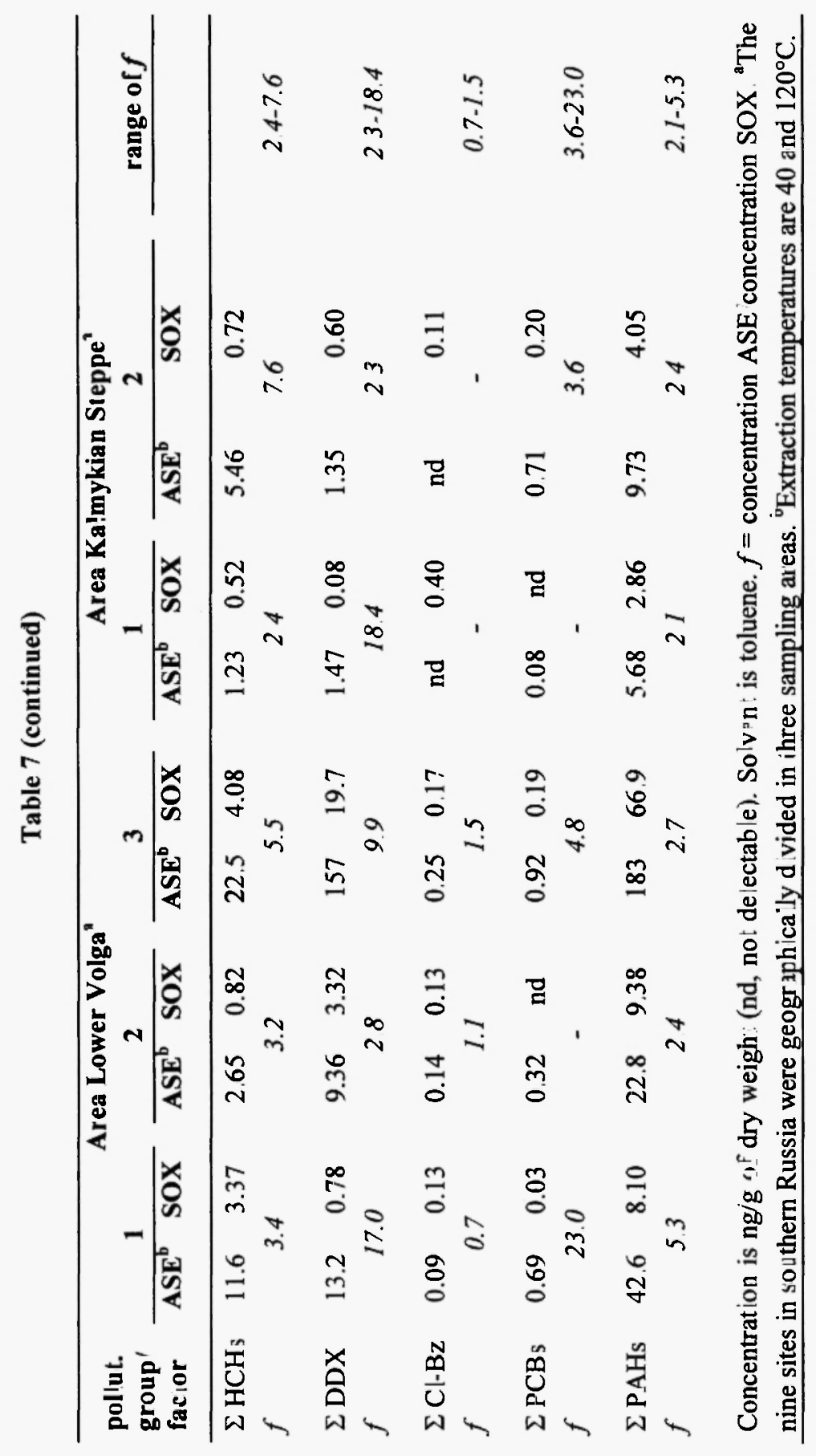




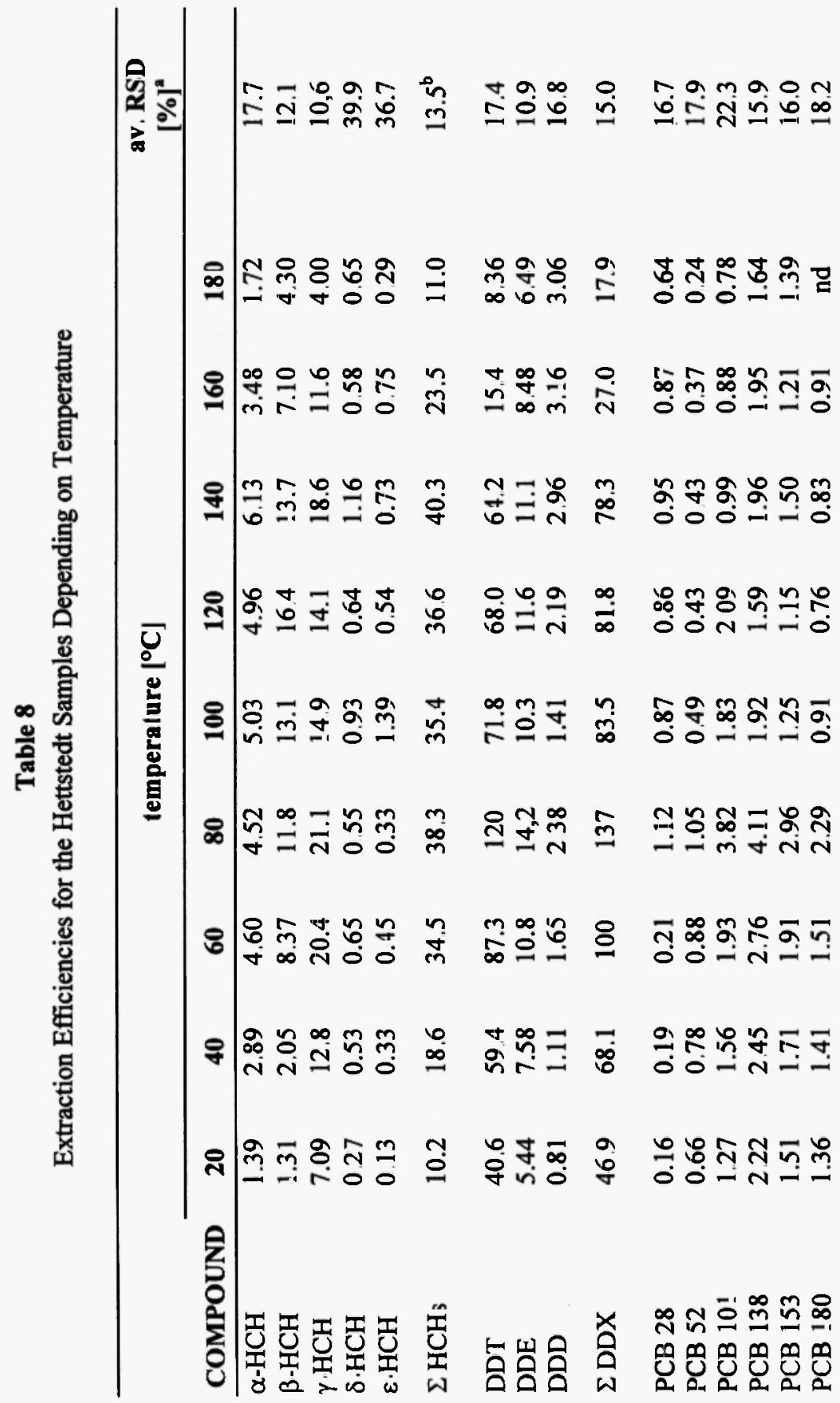




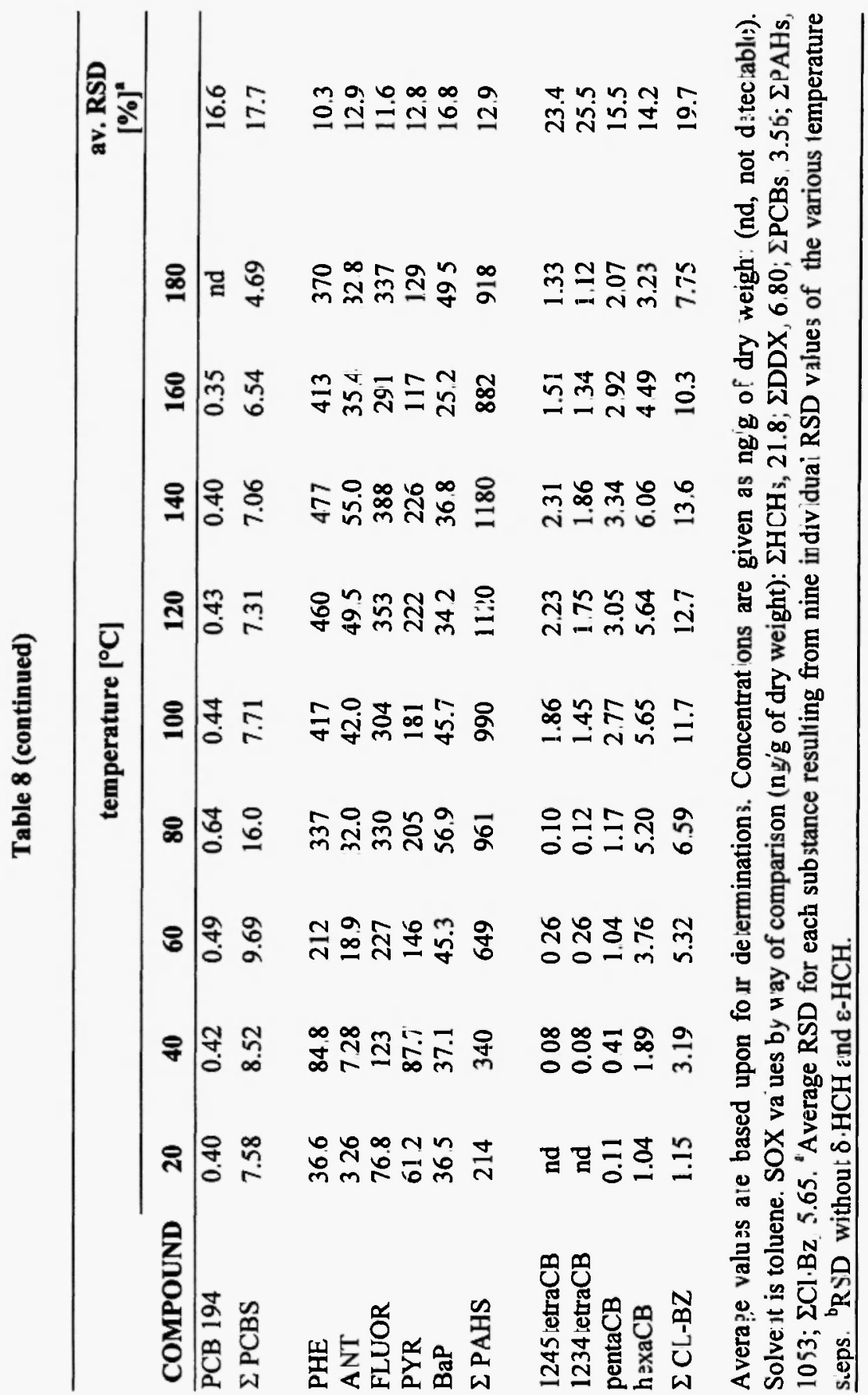




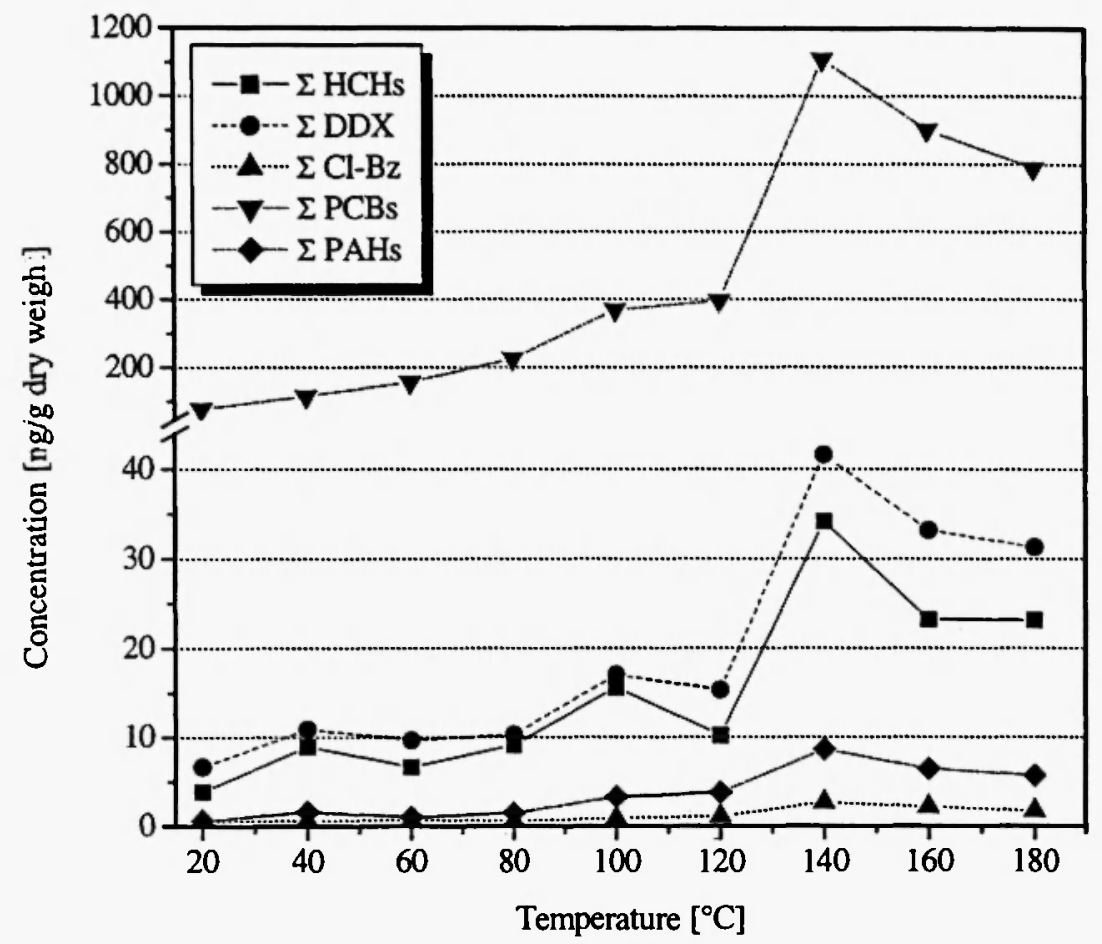

Fig. 15: Sum Curves for ASE Efficiencies of POPs and PAHs from Rösa Soil Depending on Extraction Temperature (average values based upon three determinations). Solvent is Toluene. SOX values for comparison (ng/g of dry weight): $\Sigma$ HCHs, 14.2; $\Sigma \mathrm{DDX}, 10.5$; $\Sigma$ PCBs, 0.75 ; $\Sigma$ PAHs, 122; $\Sigma \mathrm{Cl}-\mathrm{Bz}, 0.66$.

extractions were performed in the temperature range of $20-180^{\circ} \mathrm{C}$ at steps of $20^{\circ} \mathrm{C}$ using toluene as the extractant. Surprisingly, the highest extraction yields for two pollutant groups (DDX and PCBs) in the Hettstedt samples were obtained at just $80^{\circ} \mathrm{C}$; all the other pollutants required a temperature of $140{ }^{\circ} \mathrm{C}$ for the highest yields. For the site Rösa the best extraction temperature was generally $140{ }^{\circ} \mathrm{C}$. Compared to SOX, the yields achieved with ASE for the Hettstedt samples were between 1.1 and 20 times greater (Table 9). At Rösa, ASE yields exceeded those of SOX by a factor of 2.4 to 13.1 (depending on the individual pollutant groups) /51/.

The extreme extraction conditions of ASE compared to SOX may explain why part of the 'bound residues' $/ 52 /$ become available again. This is a 
Table 9

Ratio Factors $f$ for the Extraction Efficiencies of ASE vs SOX

\begin{tabular}{|c|c|c|c|c|c|}
\hline \multirow[b]{2}{*}{ temp } & \multicolumn{5}{|c|}{ pollutant group } \\
\hline & HCHs & DDX & PCBs & PAHs & $\mathbf{C l}-\mathbf{B z}$ \\
\hline & \multicolumn{5}{|c|}{ Hettstedt Samples ${ }^{b}$} \\
\hline 20 & 0.47 & 6.90 & 2.13 & 0.80 & 0.20 \\
\hline 40 & 0.85 & 10.0 & 2.39 & 0.68 & 0.57 \\
\hline 60 & 1.58 & 14.7 & 2.72 & 0.62 & 0.94 \\
\hline 80 & 1.76 & 20.2 & 4.49 & 0.91 & 1.17 \\
\hline 100 & 1.62 & 12.3 & 2.17 & 0.94 & 2.07 \\
\hline 120 & 1.68 & 12.0 & 2.05 & 1.06 & 2.25 \\
\hline 140 & 1.85 & 11.5 & 1.98 & 1.12 & 2.41 \\
\hline 160 & 1.08 & 3.97 & 1.84 & 0.84 & 1.82 \\
\hline \multirow[t]{2}{*}{180} & 0.50 & 2.63 & 1.32 & 0.87 & 1.37 \\
\hline & \multicolumn{5}{|c|}{ Rösa Samples ${ }^{c}$} \\
\hline 20 & 0.27 & 0.64 & 0.73 & 0.62 & 0.94 \\
\hline 40 & 0.63 & 1.04 & 0.84 & 0.93 & 2.42 \\
\hline 60 & 0.47 & 0.92 & 0.91 & 1.28 & 1.53 \\
\hline 80 & 0.65 & 0.98 & 0.81 & 1.85 & 2.24 \\
\hline 100 & 1.10 & 1.62 & 1.21 & 3.03 & 4.96 \\
\hline 120 & 0.72 & 1.46 & 1.47 & 3.25 & 5.71 \\
\hline 140 & 2.41 & 3.54 & 3.53 & 9.10 & 13.1 \\
\hline 160 & 1.61 & 3.16 & 2.87 & 7.39 & 9.77 \\
\hline 180 & 1.63 & 2.98 & 2.28 & 6.47 & 8.62 \\
\hline
\end{tabular}

decisive advantage of ASE compared to traditional techniques. A remarkable aspect is here the two- or even three-fold increase for all pollutant groups between 100 and $140^{\circ} \mathrm{C}$ (cf. Fig. 16), especially in view of the temperature of $100^{\circ} \mathrm{C}$ suggested by Dionex for soil extractions /42/.

\subsection{Dependence of the RSD on the extraction temperature}

The relative standard deviations in the range of $40-140{ }^{\circ} \mathrm{C}$ were on average about $10.7 \%$ (Figure 16). Higher temperatures of 160 and $180^{\circ} \mathrm{C}$ 


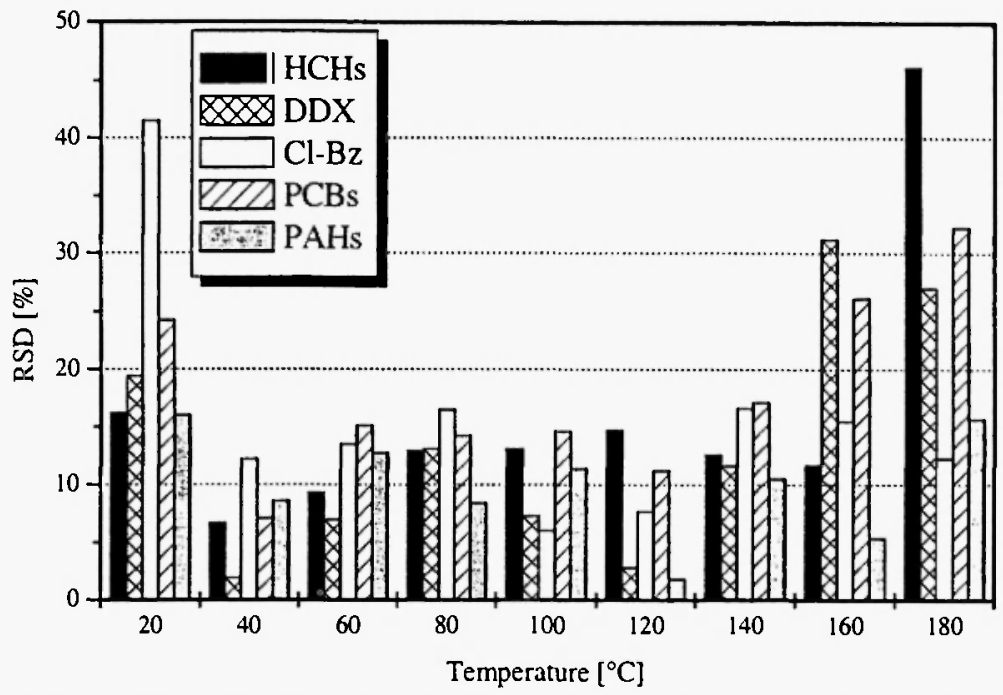

Fig. 16: RSD's for Rösa Soil Samples Depending on Temperature (Triple Determinations).

considerably increase the RSD depending on the substance concerned to as much as $47 \%$. This can be attributed to excessively high proportions of matrix components in the extract, which may have a negative impact on cleanup and analysis (interference peaks). At $20{ }^{\circ} \mathrm{C}$, the quality of the findings, reproducibility is insufficient owing to extraction conditions in the cell which are too mild (RSD $\sim 24.9 \%$ ).

\subsection{Summary: soil matrix}

Toluene is the best extractant for extracting POPs and PAHs from real soil samples. 80 and $140{ }^{\circ} \mathrm{C}$ are key temperatures at which the highest extraction efficiency is achieved depending on the soil parameters, the degree of contamination and the pollutant group /51/.

Extractions with the Dionex ASE 200 should therefore be carried out in two temperature steps of 80 and $140^{\circ} \mathrm{C}$, with a pressure of $15 \mathrm{MPa}$, and with an extraction time of $3 \times 10 \mathrm{~min}$ each.

Depending on the composition of the sample material, using ASE brought about extraction efficiencies for POPs and PAHs which were one order of magnitude or more higher than those obtained with SOX. 


\section{REASONS FOR THE MAXIMUM EXTRACTION EFFICIENCY}

Chemical species in plants and soils are known to form non-extractable or bound residues, which previously could not be extracted with methods which left the chemical nature of these residues largely intact /52/. Different types of bonding such as hydrogen-bonds, van der Waals forces, interactions due to charge transfer, entrapment in the lattice strata of clay minerals, covalent bonds with monomeric humic material precursors (lignin in plants), and incorporation into the humic material macromolecules may be responsible for the formation of these bound residues in soils and plants.

The high energy introduced during ASE (resulting from the high pressures and temperatures used) leads to a specific separation between the analyte and matrix. The reason for this could be the use of solvents above their boiling points. This reduces the viscosity and surface tension of the solvent, leading to the increased wettability of the matrix and therefore to the better penetration of the matrix by the solvent. As a result, non-covalently bonded and previously unidentifiable pollutant fractions can now also be analysed.

\section{CONCLUSIONS AND FUTURE OUTLOOK}

ASE can be used as a very successful technique for the extraction of POPs and PAHs from plant samples as well as from soil samples. In comparison to conventional extraction procedures such as USE and SOX, the extraction efficiency can be greatly increased with ASE. Only in such systematic investigations can the real potential of an extraction method be revealed, thus affording an analytical advantage. The first step of a methodological development should be to optimize the different operating variables for respective problem definition depending on the matrix used and the substance palette investigated.

In addition to purely analytical interest, the remarkable increase in extraction efficiency obtained with ASE provides a basis for continuing process-oriented works in ecotoxicology and other relevant environmental sciences.

When tackling scientific and technical fields such as the residue analysis of pollutants from soils and sediments or crops, the importance of ASE looks set to increase enormously. 


\section{ACKNOWLEDGEMENTS}

The experimental work was supported by the Ministry of Science and Art of the Free State of Saxony from Germany. We are grateful to Dr. Manz for performing the SOX investigations and to Dr. Weissflog for kindly providing test material from southern Russia.

\section{REFERENCES}

1. K.-D. Wenzel, A. Hubert, W. Engewald and G. Schuurmann, Nachrichten aus der Chemie, 1, 96 (2001).

2. F. Höfler, J. Ezzell and B. Richter, Labor Praxis, 3, 62 (1995).

3. P. Tremolada, V. Burnett, D. Calamari and K.C. Jones, Environ. Sci. Technol., 30, 3570 (1996).

4. P. Popp, P. Keil, M. Möder, A. Paschke and U. Thuss, J. Chromatogr., A774, 203 (1997).

5. C. Bandh, E. Bjorklund, L. Mathiasson, C. Näf and Y. Zebuhr, Environ. Sci. Technol., 34, 4995 (2000).

6. V. Lopez-Avila, R. Young, J. Benedicto, P. Ho, R. Kim and W.F. Beckert, Anal. Chem., 67, 2096 (1995).

7. F.I. Onuska and K.A. Terry, J. High Resolut. Chromatogr., 18, 417 (1995).

8. Z.C. Kodba and J. Marsel, Chromatographia, 49, 21 (1999).

9. O.P. Heemken, N. Theobald and B.W. Wenzlawiak, Anal. Chem., 69, 2171 (1997).

10. M.D. Burford, S.B. Hawthorne and D. Miller, J. Anal. Chem., 65, 1497 (1993).

11. K.-D. Wenzel, L. Weissflog, E. Paladini, M. Gantuz, P. Guerreiro, C. Puliafito and G. Schuurmann, Chemosphere, 34, 2505 (1997).

12. A. Reischl, M. Reissinger and O. Hutzinger, Chemosphere, 16, 2647 (1987).

13. G. Umlauf, H. Hauk and M. Reissinger, Chemosphere, 28, 1689 (1994).

14. J.J. Langenfeld, St.B. Hawthorne, D.J. Miller and J. Pawliszyn, Anal. Chem., 65, 338 (1993).

15. S.B. Hawthorn, J.J. Langenfeld, D.J. Miller and M.D. Burford, Anal. Chem., 64, 1614 (1992). 
16. N. Crain, A. Shanableh and E. Gloyna, Water Sci. Technol., 42, 363 (2000).

17. E. Bjorklund, M. Jaremo and L. Mathiasson, J. Liq. Chromatogr. R. T, 23, 2337 (2000).

18. B. Wenzlawiak, A. Hoffmann and M. Bodusz, Fresenius J. Anal. Chem., 343, 116 (1992).

19. Dionex, Sunnyvale, CA., Application Notes ASE, 313, 316, 318, 320, (1994).

20. F. Höfler, J. Ezzell and B. Richter, Labor Praxis, 4, 58 (1995).

21. J. Gan, S.K. Papiernik, W.C. Koskinen and S.R. Yates, Environ. Sci. Technol., 33, 3249 (1999).

22. I. Windal, D.J. Miller, E. De Pauw and S.B. Hawthrone, Anal. Chem., 72, 3916 (2000).

23. G.T. Tomy and G.A. Stern, Anal. Chem., 71, 4860 (1999).

24. H.J. Vandenburg, A.A. Clifford, K.D. Bartle, S.A. Zhu, J. Caroll, I.D. Newton and L.M. Garden, Anal. Chem., 70, 1943 (1998).

25. J.A. Fisher, M.J. Scarlett and A.D. Stott, Environ. Sci. Technol., 31, 1120 (1997).

26. J. Pörschmann, J. Plugge and R. Toth, J. Chromatogr. A, 909, 95 (2001).

27. B. Enders and G. Schwedt, J. prakt. Chem., 339, 250 (1997).

28. G.A. Montero, K.B. Schnelle Jr. and T.D. Giorgio, J. Environ. Sci. Health, A32 (2), 481 (1997).

29. B.E. Richter, J.L. Ezzell, D.E. Knowles and F. Höfler, Chemosphere, 34, 975 (1997).

30. D. Calamari, P. Tremolada, A. Di Guardo and M. Vighi, Environ. Sci. Technol., 28, 429 (1994).

31. W.M.J. Strachan, G. Eriksson, H. Kylin and S. Jensen, Environ. Toxicol. Chem., 13, 443 (1994).

32. K.-D. Wenzel, L. Weissflog, M. Manz, A. Hubert and G. Schüurmann, Fresen. Envir. Bull., 9, 47 (2000).

33. S.L. Simonich and R.A. Hites, Environ. Sci. Technol. 29, 2905 (1995).

34. K.-D. Wenzel, B. Mothes, L. Weissflog and G. Schüurmann, Fresen. Environ. Bull., 3, 734 (1994).

35. G. Schuürmann, K.-D. Wenzel, and L. Weissflog, in: ECOINFORMA, ed. by $K$. Alef, $H$. Fiedler and $O$. Hutzinger, Band 5 . Umweltbundesamt, Wien (Austria), 1994, p. 183. 
36. H. Kylin, E. Nordstrand, A. Sjodin and S. Jensen, Fresen. J. Anal. Chem., 356, 62 (1996).

37. M. Manz, K.-D. Wenzel, U. Dietz and G. Schüurmann, Sci. Total Environ., (accepted 2001)

38. F. Høfler, Laborpraxis, 12,44 (1996).

39. W. Klein and I. Scheunert, in: Agrochemicals, IAEA, Wien (Austria), 1982 , p. 177.

40. E.P. Lichtenstein, Residue Reviews, 76, 147 (1980).

41. E. Strasburger, in: Lehrbuch der Botanik, ed. by P. Sitte, H. Ziegler, F. Ehrendorfer and A. Bresinsky, Gustav Fischer Verlag, Stuttgart, Jena, New York, 1991, p. 213.

42. Dionex, Sunnyvale, CA., Technical Note ASE, 208, (1999).

43. K.-D. Wenzel, A. Hubert, M. Manz, L. Weissflog, W. Engewald and G. Schüurmann, Anal. Chem., 70, 4827 (1998).

44. N. Saim, J.R. Dean, M.P. Abdullah and Z. Zakaria, Anal. Chem., 70, 420 (1998).

45. G. Schüurmann, in: Ecotoxicology, ed. by G. Schüurmann and B. Markert, John Wiley and Spektrum Akademischer Verlag, New York, 1998, chapter 22.

46. I.T. Cousins, N. Hartlieb, C. Teichmann and K.C. Jones, Environ. Poll., 97, 229 (1997).

47. B. Marschner, Zeitschr. für Pflanzenernährung und Bodenkunde, 162, 1 (1999).

48. A. Sabljic, H. Güsten, H. Verhaar and J. Hermens, Chemosphere, 31, 4489 (1995).

49. W.J. Lyman, in: Handbook of Chemical Property Estimation Methods, ed. by W.J. Lyman, W.F. Reehl and O.H. Rosenblatt, American Chemical Society, Washington DC, 1990, Chapter 4.

50. L. Weissflog, K.-D. Wenzel, M. Manz, F. Kleint and G. Schüurmann, Environ. Poll., 105, 341 (1999).

51. A. Hubert, K.-D. Wenzel, M. Manz, L. Weissflog, W. Engewald and G. Schüurmann, Anal. Chem., 72, 1294 (2000).

52. F. Korte, in: Lehrbuch der Ökologischen Chemie, ed. by F. Korte, M. Bahadir, W. Klein, J.P. Lay, H. Parlar and I. Scheunert, Georg Thieme Verlag, Stuttgart, New York, 1992, p. 102. 